\title{
Metallothionein 1G promotes the differentiation of HT-29 human colorectal cancer cells
}

\author{
JUAN MARTÍN ARRIAGA ${ }^{1,2}$, ALICIA INÉS BRAVO ${ }^{3}$, JOSÉ MORDOH $^{1,2,4}$ and MICHELE BIANCHINI ${ }^{2}$ \\ ${ }^{1}$ Cancerology Laboratory, Leloir Institute, IIBBA-CONICET, Buenos Aires 1405; \\ ${ }^{2}$ Center for Oncology Research, Cancer Foundation (CIO-FUCA), Buenos Aires 1426; \\ ${ }^{3}$ Acute Interzonal General Hospiutal 'Eva Perón', Buenos Aires 1650; \\ ${ }^{4}$ Alexander Fleming Institute, Buenos Aires 1180, Argentina
}

Received September 27, 2016; Accepted November 16, 2016

DOI: $10.3892 /$ or.2017.5547

\begin{abstract}
Metallothioneins (MTs) are a family of lowmolecular-weight, cysteine-rich proteins involved in zinc and redox metabolism, that are epigenetically downregulated during colorectal cancer (CRC) progression, but may be re-induced with a variety of agents. Since loss of MT expression is associated with a worse prognosis, in the present study we investigated the effects of overexpression of the most significantly downregulated isoform in CRC, namely MT1G, on the HT-29 cell line. Overexpression of MT1G resulted in xenograft tumors with an aberrant morphology, characterized by an evident increase in mucin-containing cells that were identified as goblet cells under electron microscopy. Immunohistochemical detection of CDX2 and cytokeratin 20 was also increased, as were goblet-cell and enterocyte-specific genes by qRT-PCR. Microarray analysis of gene expression confirmed the alteration of several differentiation signaling pathways, including the Notch pathway. Using sodium butyrate and post-confluent growth as inducers of differentiation, we demonstrated that MT1G does indeed play a functional role in promoting goblet over enterocyte differentiation in vitro. Labile zinc is also induced upon differentiation of CRC cells, functionally contributing to enterocyte over goblet differentiation, as revealed using zinc-specific chelating agents. Overall, our results uncover a new tumor-suppressor activity of MT1G in promoting the differentiation of at least some
\end{abstract}

Correspondence to: Dr Juan Martín Arriaga, Cancerology Laboratory, Leloir Institute, IIBBA-CONICET, Avenida Patricias Argentinas 435, Buenos Aires 1405, Argentina

E-mail:jm_arriaga@yahoo.com.ar

Abbreviations: BUT, sodium butyrate; CRC, colorectal cancer; FZ, fluozin 3-AM; MMPs, matrix metalloproteinases; TPEN, N,N,N',N'tetrakis(2-pyridylmethyl) ethylenediamine; MTs, metallothioneins

Key words: metallothioneins, labile zinc, colorectal cancer, goblet cells, differentiation
CRC tumors, and implicate MTs and zinc signaling as new players in colorectal differentiation. This further contributes to the hypothesis that re-induction of MTs may have therapeutic value by diminishing the aggressiveness of CRC tumors.

\section{Introduction}

Colorectal cancer (CRC) is the third most commonly diagnosed cancer worldwide, having a mortality rate near $50 \%$ (1). Recent studies have shown that these tumors retain multilineage differentiation processes similar to those of the normal intestinal epithelium, mainly the goblet cell and enterocyte lineages (2). Furthermore, molecular classifications representing these cellular phenotypes can have prognostic value and be predictive of response to different therapeutic agents (3).

Metallothioneins (MTs) are a family of low-molecularweight, cysteine-rich proteins involved in zinc and redox metabolism. By chelating zinc ions through redox-active thiol groups, they have the capacity to regulate the exchangeable, loosely-bound pool of intracellularzinc,termed the 'labile' pool, which participates in zinc transfer reactions and intracellular signaling. Thus MTs have been implicated in many aspects of tumor biology, such as proliferation, differentiation, apoptosis, angiogenesis, redox and zinc homeostasis, anti-inflammatory reactions and immunomodulation (4-7). The human genome encodes at least 11 functional MT isoforms that share structural and functional similarities. Due to their structural similarity, commercially available antibodies do not distinguish between individual MT isoforms, and therefore their individual mRNA expression levels can be measured by qRT-PCR. However, due to the fact that they are variably expressed in tissues and induced by several stimuli, it is possible that different tumors express distinct MT genes, which could help explain the conflicting data on MT function in different tumor types $(6,7)$. We and others have previously shown that multiple MT1 isoforms and MT2A are downregulated during CRC progression (especially isoform MT1G) mainly through epigenetic mechanisms, and that this is associated with shorter patient survival (8-11). Several agents such as DNA methyltransferase inhibitors, histone deacetylase inhibitors or zinc are capable of re-inducing MT expression in colorectal tumors, which can 
slow down in vivo tumor growth and sensitize these tumors to chemotherapeutic agents (12).

In order to help understand the phenotypic consequences of MT induction, in the present study we investigated the effects of stable overexpression of the most downregulated isoform in CRC, namely MT1G, on the HT-29 CRC cell line. We uncovered a new role for this isoform in modulating tumor differentiation and thus expand the mechanisms by which this gene may act as a tumor suppressor in CRC.

\section{Materials and methods}

Reagents and cell lines. The MT1G cDNA was cloned into the pcDNA3.1/myc-His(-)A expression vector, resulting in an MT1G-myc fusion protein as previously described (12). Sodium butyrate and N,N,N',N'-tetrakis(2-pyridylmethyl) ethylenediamine (TPEN) were purchased from Sigma-Aldrich Inc. (St. Louis, MO, USA), and FluoZin-3-AM (FZ) from Invitrogen (San Diego, CA, USA). The human CRC cell lines HT-29 and HCT116 were obtained from the American Type Culture Collection (ATCC; Manassas, VA, USA), maintained as previously described (8), and subjected to STR profiling for authentication after all experiments were finalized. For post-confluent growth, day 0 was considered the day when cells reached $100 \%$ confluence, and fresh medium was replaced every 1-2 days thereafter.

Animal studies and histological procedures. Eightto 10 -week-old male nude mice were subcutaneously injected ( $2 \times 10^{6}$ cells each) with two independent clones of MOCK or

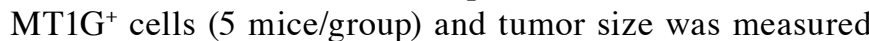
with a caliper to calculate tumor volume using the formula: Tumor volume $\left(\mathrm{mm}^{3}\right)=[$ length $(\mathrm{mm})] \mathrm{x}$ [width $\left.(\mathrm{mm})\right]^{2} \mathrm{x} \pi / 6$. All animal procedures were approved by the Institutional Animal Care Board of the Leloir Institute. After 50 days, tumors were excised, formalin-fixed and paraffin-embedded for histological examination. A fraction of each tumor was preserved in RNAlater medium (Ambion Inc., Austin TX, USA) at $4^{\circ} \mathrm{C}$ for $24 \mathrm{~h}$, and then stored at $-80^{\circ} \mathrm{C}$. RNA was extracted from RNAlater-preserved tissues using the TRIzol method (Invitrogen), and quantification and quality control were performed with the Agilent 2100 Bioanalyzer (Agilent Technologies, Santa Clara, CA, USA). Paraffin sections ( $4 \mu \mathrm{m}$ thick) were re-hydrated and stained with Alcian Blue stain (1\% in $3 \%$ acetic acid, $\mathrm{pH} 2.5$ ) or processed for immunohistochemistry using the Vectastain Universal Elite ABC kit (Vector Laboratories, Inc., Burlingame, CA, USA) with citrate buffer antigen retrieval and the following antibodies: anti-cytokeratin 20 (KS 20.8; Dako Corporation, Carpinteria, CA, USA) and anti-CDX2 (clone EPR2764Y; Cell Marque, Rocklin, CA, USA).

For transmission electron microscopy, freshly xenografted tumors were cut into small ( $\sim 1-\mathrm{mm}$ thick) pieces and promptly fixed in $2.5 \%$ glutaraldehyde in phosphate-buffered saline (PBS) for $2 \mathrm{~h}$, washed and fixed for $90 \mathrm{~min}$ in $1 \%$ osmium tetroxide in phosphate-buffered saline (PBS), de-hydrated in acetone gradients and included in resin. Semi- $(0.5 \mu \mathrm{m})$ and ultra-thin $(70 \mathrm{~nm})$ sections were cut and contrasted in $2.5 \%$ uranyl-acetate, and visualized using a Zeiss EM 109T microscope coupled to a digital CCD Gatan ES1000W camera.
Gene expression profile analysis and $q R T-P C R$. Total RNA was extracted, and mRNA expression was analyzed using an Agilent Custom microarray 8x15K (Agilent Technologies, Palo Alto, CA, USA), which contained 15,744 oligonucleotide probes representing $>8,200$ different human transcripts. Two samples from each group were used to detect mRNA expression; each biological replicate was run in duplicate, and the fluorochromes were swapped to reduce dye-bias; in total eight $15 \mathrm{~K}$ microarrays were scanned using the Axon Confocal Scanner 4000B (Molecular Devices, Sunnyvale, CA, USA) with optimized settings: dye channel, $635 \mathrm{~nm}, \mathrm{PMT}=720$, laser power, $30 \%$, scan resolution, $10 \mathrm{~nm}$; dye channel, $532 \mathrm{~nm}$, $\mathrm{PMT}=540$, laser power, $30 \%$, scan resolution, $10 \mathrm{~nm}$; line average, 4 lines. The data were analyzed using GenePix ${ }^{\circledR}$ Pro 6 Microarray Acquisition and Analysis Software (Molecular Devices) and normalized with the MIDAS v2.2: Microarray Data Analysis System (TIGR's Microarray Data Analysis System). Normalization was necessary to compensate for variability between slides and fluorescent dyes. To this end we employed a locally weighted linear regression [Lowess $(13,14)]$; data were filtered using low-intensity cutoff and replicate consistency trimming.

The differentially expressed genes among the $\mathrm{MT}_{1 \mathrm{G}}{ }^{+}$, and control (MOCK) sets were identified using the significant analysis of microarray (SAM) statistical software from MultiExperiment Viewer (MeV) (TIGR's Microarray Data Analysis System). In the comparisons of $\mathrm{MT}^{+} \mathrm{G}^{+}$vs. MOCK, the genes that were all upregulated in the comparisons were identified as the persistently upregulated genes, and the genes that were all downregulated in the comparisons were defined as the persistently downregulated genes.

The gene annotation enrichment analysis using Gene Ontology (GO) (http://www.geneontology.org/) and Kyoto Encyclopedia of Genes and Genomes (KEGG) (http://www. genome.jp/kegg/) data for gene sets was performed using Database for Annotation, Visualization, and Integrated Discovery (DAVID) software $(15,16)$. A Benjamini p-value of 0.05 was used in the analysis.

Quantitative reverse-transcription PCR (qRT-PCR) was used to quantify mRNA levels as previously described (8). Briefly, PCR runs were carried out using SYBR Universal Master Mix (Applied Biosystems, Carlsbad, CA, USA), and relative expression levels were determined by the $\Delta \Delta \mathrm{Ct}$ method using ACTB gene expression to normalize all samples. The primers used are listed in Table I.

Alkaline phosphatase activity measurement. The activity of this enzyme was used as a marker of differentiation of HT-29 cells (17). For this purpose, confluent cell lines were lysed in $10 \mathrm{mM}$ Tris (pH 7.4), $1 \mathrm{mM} \mathrm{MgCl}$, $20 \mu \mathrm{M} \mathrm{ZnCl}_{2}$, $0.2 \%$ Triton $\mathrm{X}-100+$ protease inhibitors, and incubated with NBT-BCIP as the chromogenic substrate for $16 \mathrm{~h}$ at $37^{\circ} \mathrm{C}$. The resulting brown precipitate was solubilized in $10 \%$ SDS, $10 \%$ $\mathrm{HCl}$ and absorbance was measured at $595 \mathrm{~nm}$.

siRNA transfection. Two siRNAs targeting the MT1G isoform (si1G.1 and si1G.2) and one targeting all functional MT-1 and MT-2 isoforms were previously validated (12), and transfected at $125 \mathrm{nM}$ using LF2000 (Invitrogen) as described by the manufacturer. After $24 \mathrm{~h}$ of siRNA treatment, medium was replaced 
Table I. Primer sequences.

\begin{tabular}{lll}
\hline Gene & \multicolumn{1}{c}{ Forward primer } & \multicolumn{1}{c}{ Reverse primer } \\
\hline MT1G & CTTCTCGCTTGGGAACTCTA & AGGGGTCAAGATTGTAGCAAA \\
MT2A & GCAACCTGTCCCGACTCTAG & TTGCAGGAGGTGCATTTG \\
ACTB & GCCATCTCTTGCTCGAAGTCCAG & ATGTTTGAGACCTTCAACACCCC \\
CDKN1A & AAGACCATGTGGACCTGT & GGTAGAAATCTGTCATGCTG \\
HSI & GAGGACACTGGCTTGGAGAC & ATCCAGCGGGTACAGAGATG \\
HALPI & GACCACTCCCATGTCTTCTCCTT & TCGCACGCCTGAGTTGAA \\
CA2 & CCGCGGACACACAGTGCAGG & CCAGTGCTCAGGTCCGTTGTGT \\
CA1 & CAGAACATACAGTGGATGGAGTCAA & GGCCTCACCAACCTTCATCA \\
ATOH1 & AAATGCTCGGTGTGTCCTG & ACTTCCTCCTGATGCTCCTT \\
TFF3 & CCCCGGGAGCATCTTG & GGGACCGAGGCGAAGTT \\
HMUC2 & CTCCAGCTCTGCTGAGGAGT & GCTTGAAACACCAAGGCACT \\
CDX2 & CAGCACCGATTGCTGAGTTG & GCTGGTCATCTCAATGGCAG \\
\end{tabular}

with or without $2 \mathrm{mM}$ sodium butyrate for $48 \mathrm{~h}$, and cells were collected for RNA extraction or ALP activity measurement.

Scratch assays and gelatin zymography. We used the scratch assay to estimate the migration capacities of $\mathrm{MOCK}$ and $\mathrm{MT}^{+} \mathrm{G}^{+}$ cell lines, which were plated in triplicate in 24 -well plates until they reached confluence. Two perpendicular scratches were made with a pipette tip, after which the cells were washed thrice in PBS and replaced with $1 \%$ fetal bovine serum (FBS) medium. Areas with the same wound length were selected and photographed until complete wound closure. Wound closure at a given time $t$ was calculated as: (initial wound length - wound length at time $\mathrm{t}$ )/initial wound length $\mathrm{x} 100$.

To determine gelatinase activity of matrix metalloproteinases (MMPs), upon reaching confluence medium was replaced with serum-free Dulbecco's modified Eagle's medium (DMEM) for $24 \mathrm{~h}$, and the conditioned medium was centrifuged at 1,200 x g for $5 \mathrm{~min}$, and immediately loaded into $10 \%$ polyacrylamide electrophoretic gels with or without $2.5 \mathrm{mg} / \mathrm{ml}$ gelatin (Sigma-Aldrich) as described in (18). Coomasie Blue staining of the non-gelatin gels were used as a loading control.

Measurement of intracellular labile zinc. For this purpose we employed the cell-permeable zinc-specific fluorophore FZ as described in (12). Briefly, cells were plated in triplicate in sterile plastic coverslips (for fluorescence microscopy) or in 96-well plates (for fluorimetric analysis), and incubated for $30 \mathrm{~min}$ at room temperature with $2 \mu \mathrm{M}$ FZ in PBS, washed in PBS and incubated a further 30 min in PBS at room temperature. Propidium iodide staining was used to control for plating differences and data are expressed as normalized fluorescence $\mathrm{FZ}=(\mathrm{F}-\mathrm{FTPEN}) /(\mathrm{FZn}-\mathrm{FTPEN})$, so as to get values relative to a 'maximum' intensity given by pretreatment with zinc $400 \mu \mathrm{M}$ for $8 \mathrm{~h}$ (FZn, resulting in $\mathrm{FZ}=1$ ) and a 'minimum' intensity given by $20 \mu \mathrm{M}$ TPEN treatment during the final 30 min incubation of fluozin (FTPEN, resulting in $\mathrm{FZ}=0$ ). This score allowed us to better compare results of the different experiments.
Statistical analysis. Data are expressed as mean \pm SEM and p-values $<0.05$ were considered significant. Comparison of means was carried out using Student's t-test, with one-way ANOVA followed by Dunnett's post hoc t-test for three or more groups, or with two-way ANOVA followed by Bonferroni's post hoc t-test for two variables. GraphPad Prism 5.0 (GraphPad Software, Inc., La Jolla, CA, USA) software was used for analysis.

\section{Results}

MT1G overexpression in the HT-29 CRC cell line. We stably expressed MT1G as a myc-epitope fusion protein in HT-29 cells. When grown in vivo as subcutaneous xenografts on nude mice, these $\mathrm{MT} 1 \mathrm{G}^{+}$cells grew at similar rates compared to the empty-vector ('MOCK')-transfected cells (data not shown), in stark contrast to the antiproliferative effects we had previously observed using the HCT116 cell line (12). However, hematoxylin and eosin (H\&E) staining (Fig. 1A) showed that $\mathrm{MT}_{1} \mathrm{G}^{+}$ tumors contained a higher number of mucin-containing, Alcian Blue-positive cells (Fig. 1B) that were confirmed to be goblet cells by transmission electron microscopy (Fig. 1C). Nuclear expression of the intestine-specific homeobox transcription factor CDX2 was markedly enhanced in the $\mathrm{MT} \mathrm{G}^{+}$tumors, as shown by immunohistochemical staining on Fig. 1D, as was also the intensity of cytokeratin 20 (Fig. 1E). The latter also suggests that commitment to the enterocyte lineage may be enhanced as well. Indeed, both goblet-associated (TFF3, $A T O H 1$ and $M U C 2$ ) and enterocyte-associated genes (HSI, $C A 2$ and $A L P I)$ were overexpressed in the $\mathrm{MT} 1 \mathrm{G}^{+}$tumors by qRT-PCR analysis (Fig. 1F), suggesting that $\mathrm{MT} \mathrm{G}^{+}$tumors are more differentiated than MOCK controls.

Gene expression analysis of $H T-29 M T 1 G^{+}$tumors using cDNA microarrays. We then used cDNA microarrays to profile the mRNA expression of MOCK and $\mathrm{MT}^{\mathrm{M}} \mathrm{G}^{+} \mathrm{HT}-29$ xenografts, derived from two different $\mathrm{MT} \mathrm{G}^{+}$or $\mathrm{MOCK}$ clonal cell lines (MT1G-1 and MT1G-2, or MOCK-1 and 

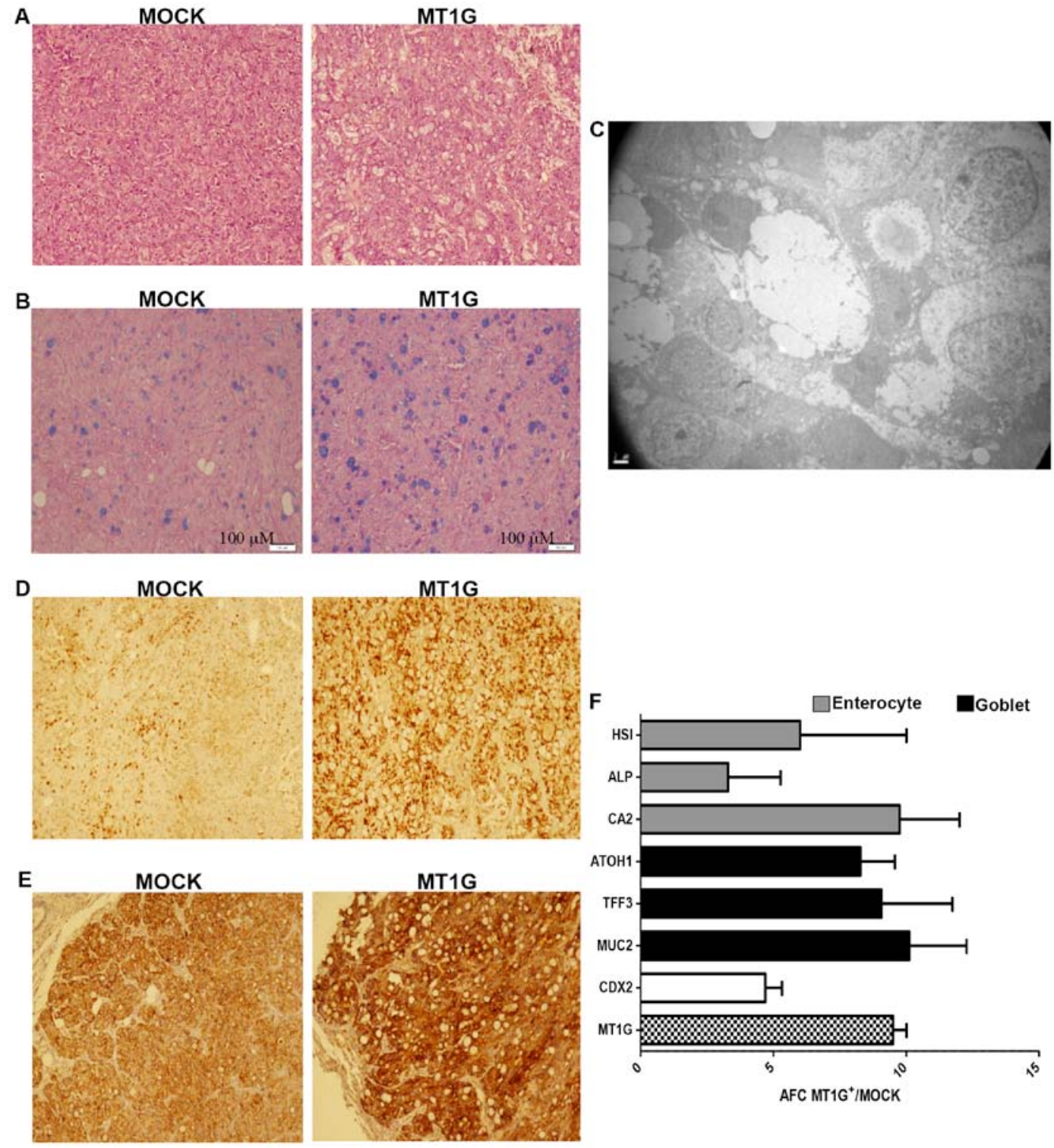

Figure 1. HT-29 MOCK and $\mathrm{MT} 1 \mathrm{G}^{+}$subcutaneous xenografts in nude mice. (A) H\&E and (B) Alcian Blue stainings showing an increase in the number of mucin-like cells in the $\mathrm{MT}_{1} \mathrm{G}^{+}$tumors. (C) Microphotograph of a goblet-like cell in MT1G+ tumors. (D) CDX2 and (E) keratin 20 immunohistochemistry. (F) Expression of enterocyte and goblet-associated differentiation markers, as assessed by qRT-PCR. AFC, average fold-change.

MOCK-2, respectively). Gene expression profiles of the biological replicates were reproducible and highly correlated (Pearson's correlation coefficient 0.81 ). Analysis of data with Rank product analysis revealed significant gene expression differences among the groups, with a total of 305 known genes found to be consistently upregulated or downregulated in the

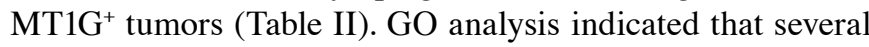
functional categories were enriched by DAVID, and included upregulated genes associated with cell differentiation, cell fate commitment and Notch signaling pathway, as well as downregulated genes in the categories of regulation of apoptosis, cell migration and cell proliferation (Table III). Differentially expressed genes were also analyzed for KEGG pathway enrichment and two significantly enriched pathways were identified between upegulated or downregulated genes: the Notch signaling pathway and pathways in cancer, respectively.

Given the finding of downregulated genes in the cell migration category, we performed migration 'scratch' assays in the HT-29 and HCT116 cell lines overexpressing MT1G, and found in both cell lines a statistically significant reduction in migration rates upon MT1G overexpression (Fig. 2A and B). Gelatin zymography using conditioned media from these cells, however, revealed no differences in MMP2 activity (Fig. 2C).

Next, in order to further investigate the involvement of MT1G in the differentiation of HT-29 cells, we used two different and well-known cell culture conditions to stimulate the in vitro differentiation of these cells: sodium butyrate (BUT) treatment (19) and post-confluent cell growth (20). We used TFF3 and MUC2 mRNA expression as surrogate markers for the goblet cell lineage, and HSI and CAI mRNAs, along with enzymatic alkaline-phosphatase activity (ALP) for enterocytes.

Involvement of MT1G in butyrate-mediated differentiation of HT-29 cells. Sodium butyrate is a well-known inducer of differentiation in CRC cell lines (21), and indeed, as shown in 
Table II. List of all significantly differentially expressed genes in MT1G+ vs. MOCK HT-29 xenografts.

A, Upregulated genes

\begin{tabular}{|c|c|c|c|c|c|}
\hline Gene reference & Gene symbol & Name & Mean & $\begin{array}{l}\text { P-values } \\
\text { (Up) }\end{array}$ & $\begin{array}{l}\text { RP-values } \\
\quad(\mathrm{Up})\end{array}$ \\
\hline NM_138444 & KCTD12 & $\begin{array}{l}\text { Potassium channel tetramerisation } \\
\text { domain containing } 12\end{array}$ & 2.65 & $2.81 \mathrm{E}-06$ & 80.00 \\
\hline NM_000051 & ATM & Ataxia telangiectasia mutated & 2.52 & $4.68 \mathrm{E}-06$ & 91.77 \\
\hline NM_175698 & SSX2 & Synovial sarcoma, $\mathrm{X}$ breakpoint 2 & 3.06 & $6.56 \mathrm{E}-06$ & 99.19 \\
\hline NM_031964 & KRTAP17-1 & Keratin-associated protein $17-1$ & 2.35 & $2.25 \mathrm{E}-05$ & 141.15 \\
\hline NM_003357 & SCGB1A1 & $\begin{array}{l}\text { Secretoglobin, family } 1 \mathrm{~A}, \text { member } 1 \\
\text { (uteroglobin) }\end{array}$ & 2.19 & $2.72 \mathrm{E}-05$ & 155.94 \\
\hline NM_005430 & WNT1 & $\begin{array}{l}\text { Wingless-type MMTV integration } \\
\text { site family, member } 1\end{array}$ & 2.40 & $2.81 \mathrm{E}-05$ & 156.29 \\
\hline NM_001031672 & CYB5RL & Cytochrome b5 reductase-like & 2.37 & $3.18 \mathrm{E}-05$ & 164.29 \\
\hline NM_000546 & TP53 & Tumor protein $\mathrm{p} 53$ & 2.12 & $3.75 \mathrm{E}-05$ & 168.99 \\
\hline NM_001123065 & & Chromosome 7 open reading frame 65 & 2.04 & $4.59 \mathrm{E}-05$ & 181.40 \\
\hline NM_001443 & FABP1 & Fatty acid binding protein 1 , liver & 2.27 & $5.99 \mathrm{E}-05$ & 197.89 \\
\hline NM_000364 & TNNT2 & Troponin T type 2 (cardiac) & 2.01 & 8.24E-05 & 216.07 \\
\hline NM_001201 & BMP3 & Bone morphogenetic protein 3 & 2.17 & $1.01 \mathrm{E}-04$ & 224.84 \\
\hline NM_031310 & PLVAP & Plasmalemma vesicle-associated protein & 2.02 & $1.22 \mathrm{E}-04$ & 239.78 \\
\hline NM_182981 & OSGIN1 & Oxidative stress induced growth inhibitor 1 & 1.89 & $1.44 \mathrm{E}-04$ & 249.22 \\
\hline NM_139211 & HOPX & HOP homeobox & 1.88 & $1.65 \mathrm{E}-04$ & 256.18 \\
\hline NM_017774 & CDKAL1 & $\begin{array}{l}\text { CDK5 regulatory subunit-associated } \\
\text { protein } 1 \text {-like } 1\end{array}$ & 1.86 & $2.00 \mathrm{E}-04$ & 271.00 \\
\hline NM_001077195 & ZNF436 & Zinc finger protein 436 & 1.96 & 2.62E-04 & 289.52 \\
\hline NM_000067 & $\mathrm{CA} 2$ & Carbonic anhydrase II & 1.76 & 2.82E-04 & 295.37 \\
\hline NM_015894 & STMN3 & Stathmin-like 3 & 1.17 & $2.86 \mathrm{E}-04$ & 296.25 \\
\hline NM_014237 & ADAM18 & ADAM metallopeptidase domain 18 & 2.19 & $2.95 \mathrm{E}-04$ & 298.48 \\
\hline NM_182705 & FAM101B & Family with sequence similarity 101 , member B & 1.81 & 4.28E-04 & 330.71 \\
\hline NM_025191 & EDEM3 & ER degradation enhancer, $\alpha$-mannosidase-like 3 & 1.78 & $4.56 \mathrm{E}-04$ & 337.06 \\
\hline NM_020639 & RIPK4 & Receptor-interacting serine-threonine kinase 4 & 1.70 & $4.56 \mathrm{E}-04$ & 337.43 \\
\hline NM_004557 & NOTCH4 & Notch 4 & 1.70 & 4.77E-04 & 340.80 \\
\hline NM_005618 & DLL1 & 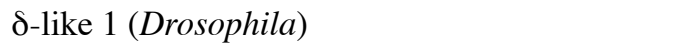 & 1.70 & $5.05 \mathrm{E}-04$ & 346.21 \\
\hline NM_004001 & FCGR2B & $\begin{array}{l}\text { Fc fragment of } \mathrm{IgG} \text {, low affinity } \mathrm{IIb} \text {, } \\
\text { receptor }(\mathrm{CD} 32)\end{array}$ & 1.71 & $5.22 \mathrm{E}-04$ & 349.94 \\
\hline NM_001008225 & CNOT4 & CCR4-NOT transcription complex, subunit 4 & 1.66 & $6.17 \mathrm{E}-04$ & 367.80 \\
\hline NM_170664 & OTOA & Otoancorin & 1.64 & $6.23 \mathrm{E}-04$ & 368.88 \\
\hline NM_019845 & RPRM & $\begin{array}{l}\text { Reprimo, TP53-dependent G2 arrest } \\
\text { mediator candidate }\end{array}$ & 1.39 & $6.24 \mathrm{E}-04$ & 369.37 \\
\hline NM_033409 & SLC52A3 & Chromosome 20 open reading frame 54 & 1.65 & $6.26 \mathrm{E}-04$ & 369.79 \\
\hline NM_001010879 & ZIK1 & $\begin{array}{l}\text { Zinc finger protein interacting with } \\
\mathrm{K} \text { protein } 1 \text { homolog (mouse) }\end{array}$ & 1.59 & $6.68 \mathrm{E}-04$ & 376.61 \\
\hline NM_007365 & PADI2 & Peptidyl arginine deiminase, type II & 1.98 & 6.99E-04 & 381.36 \\
\hline NM_007314 & ABL2 & $\begin{array}{l}\text { v-abl Abelson murine leukemia viral } \\
\text { oncogene homolog } 2\end{array}$ & 0.99 & $7.21 \mathrm{E}-04$ & 385.01 \\
\hline NM_001080519 & BAHCC1 & BAH domain and coiled-coil containing 1 & 1.58 & $7.93 \mathrm{E}-04$ & 397.25 \\
\hline NM_000584 & CXCL8 & Interleukin 8 & 1.68 & $9.46 \mathrm{E}-04$ & 419.56 \\
\hline NM_002649 & PIK3CG & $\begin{array}{l}\text { Phosphoinositide-3-kinase, catalytic, } \\
\gamma \text {-polypeptide }\end{array}$ & 1.74 & $1.07 \mathrm{E}-03$ & 437.34 \\
\hline NM_178311 & GGTLC1 & $\gamma$-glutamyltransferase light chain 1 & 1.28 & $1.09 \mathrm{E}-03$ & 440.27 \\
\hline NM_001124756 & PABPC1L & Poly(A) binding protein, cytoplasmic 1-like & 1.51 & $1.11 \mathrm{E}-03$ & 442.81 \\
\hline NM_001010926 & HES5 & Hairy and enhancer of split 5 (Drosophila) & 1.09 & $1.15 \mathrm{E}-03$ & 446.74 \\
\hline NM_152643 & KNDC1 & Kinase non-catalytic C-lobe domain (KIND) & 1.85 & $1.18 \mathrm{E}-03$ & 449.71 \\
\hline
\end{tabular}


Table II. Continued.

\begin{tabular}{|c|c|c|c|c|c|}
\hline Gene reference & Gene symbol & Name & Mean & $\begin{array}{l}\text { P-values } \\
\text { (Up) }\end{array}$ & $\begin{array}{l}\text { RP-values } \\
\quad(\mathrm{Up})\end{array}$ \\
\hline NM_152279 & ZNF585B & Zinc finger protein 585B & 1.30 & $1.18 \mathrm{E}-03$ & 450.06 \\
\hline NM_003018 & SFTPC & Surfactant protein $\mathrm{C}$ & 1.51 & $1.20 \mathrm{E}-03$ & 452.03 \\
\hline NM_003460 & $\mathrm{ZP} 2$ & $\begin{array}{l}\text { Zona pellucida glycoprotein } 2 \\
\text { (sperm receptor) }\end{array}$ & 1.79 & $1.23 \mathrm{E}-03$ & 456.86 \\
\hline NM_022101 & & Chromosome $\mathrm{X}$ open reading frame 56 & 0.84 & $1.30 \mathrm{E}-03$ & 464.79 \\
\hline NM_001136566 & RAD21L1 & RAD21-like 1 (S.pombe) & 0.61 & $1.31 \mathrm{E}-03$ & 465.53 \\
\hline NM_019886 & CHST7 & $\begin{array}{l}\text { Carbohydrate (N-acetylglucosamine 6-O) } \\
\text { sulfotransferase } 7\end{array}$ & 1.49 & $1.43 \mathrm{E}-03$ & 477.78 \\
\hline NM_002410 & MGAT5 & $\begin{array}{l}\text { Mannosyl ( } \alpha-1,6-) \text {-glycoprotein } \\
\beta-1,6-N-\text { acetyl-glucosaminyltransferase }\end{array}$ & 1.37 & $1.49 \mathrm{E}-03$ & 484.02 \\
\hline NM_001130715 & PLAC8 & Placenta-specific 8 & 1.47 & $1.51 \mathrm{E}-03$ & 485.05 \\
\hline NM_012368 & OR2C1 & $\begin{array}{l}\text { Olfactory receptor, family } 2 \text {, subfamily } \mathrm{C} \text {, } \\
\text { member } 1\end{array}$ & 1.42 & 1.60E-03 & 493.64 \\
\hline NM_198463 & C3ORF67 & Chromosome 3 open reading frame 67 & 1.55 & $1.72 \mathrm{E}-03$ & 503.50 \\
\hline NM_080647 & TBX1 & T-box 1 & 1.01 & $1.74 \mathrm{E}-03$ & 504.66 \\
\hline NM_001136003 & $\mathrm{C} 2 \mathrm{CD} 4 \mathrm{D}$ & $\mathrm{C} 2$ calcium-dependent domain containing 4D & 1.38 & $1.83 \mathrm{E}-03$ & 512.27 \\
\hline NM_014909 & VASH1 & Vasohibin 1 & 1.38 & $1.84 \mathrm{E}-03$ & 512.54 \\
\hline NM_002318 & LOXL2 & Lysyl oxidase-like 2 & 1.44 & $1.91 \mathrm{E}-03$ & 518.96 \\
\hline NM_031457 & MS4A8 & $\begin{array}{l}\text { Membrane-spanning 4-domains, } \\
\text { subfamily A, member } 8 \mathrm{~B}\end{array}$ & 1.36 & $2.17 \mathrm{E}-03$ & 538.29 \\
\hline NM_001146190 & ZNF407 & Zinc finger protein 407 & 1.35 & $2.20 \mathrm{E}-03$ & 541.10 \\
\hline NM_004375 & COX11 & $\begin{array}{l}\text { COX } 11 \text { cytochrome } c \text { oxidase assembly } \\
\text { homolog (yeast) }\end{array}$ & 1.37 & $2.36 \mathrm{E}-03$ & 552.91 \\
\hline NM_001040462 & BTNL8 & Butyrophilin-like 8 & 0.84 & $2.39 \mathrm{E}-03$ & 554.54 \\
\hline NM_001265 & $\mathrm{CDX} 2$ & Caudal type homeobox 2 & 1.33 & $2.44 \mathrm{E}-03$ & 558.57 \\
\hline NM_001013661 & VSIG8 & $\begin{array}{l}\text { V-set and immunoglobulin domain } \\
\text { containing } 8\end{array}$ & 1.33 & $2.50 \mathrm{E}-03$ & 563.31 \\
\hline NM_019119 & PCDHB9 & Protocadherin- $\beta 9$ & 1.32 & $2.51 \mathrm{E}-03$ & 564.49 \\
\hline NM_001144875 & DOK3 & Docking protein 3 & 1.29 & $2.54 \mathrm{E}-03$ & 566.33 \\
\hline NM_003722 & TP63 & Tumor protein p63 & 1.38 & $2.56 \mathrm{E}-03$ & 569.10 \\
\hline NM_006138 & MS4A3 & $\begin{array}{l}\text { Membrane-spanning 4-domains, subfamily A, } \\
\text { member } 3 \text { (hematopoietic cell-specific) }\end{array}$ & 1.58 & $2.73 \mathrm{E}-03$ & 580.41 \\
\hline NM_005427 & TP73 & Tumor protein p73 & 1.37 & $2.88 \mathrm{E}-03$ & 589.30 \\
\hline NM_003106 & SOX2 & SRY (sex determining region Y)-box 2 & 1.07 & $3.12 \mathrm{E}-03$ & 604.10 \\
\hline NM_033318 & SMDT1 & Chromosome 22 open reading frame 32 & 0.80 & $3.14 \mathrm{E}-03$ & 605.59 \\
\hline NM_012426 & SF3B3 & Splicing factor $3 \mathrm{~b}$, subunit $3,130 \mathrm{kDa}$ & 1.31 & $3.31 \mathrm{E}-03$ & 615.60 \\
\hline NM_002458 & MUC5B & Mucin 5B, oligomeric mucus/gel-forming & 1.53 & $3.45 \mathrm{E}-03$ & 623.75 \\
\hline NM_001001411 & ZNF676 & Zinc finger protein 676 & 1.45 & $3.48 \mathrm{E}-03$ & 625.90 \\
\hline NM_000362 & TIMP3 & TIMP metallopeptidase inhibitor 3 & 1.33 & $3.55 \mathrm{E}-03$ & 629.94 \\
\hline NM_014751 & MTSS1 & Metastasis suppressor 1 & 1.23 & $3.62 \mathrm{E}-03$ & 633.32 \\
\hline NM_201442 & $\mathrm{C} 1 \mathrm{~S}$ & Complement component $1, \mathrm{~s}$ subcomponent & 0.91 & 3.63E-03 & 633.68 \\
\hline NM_005961 & MUC6 & Mucin 6, oligomeric mucus/gel-forming & 1.21 & $3.92 \mathrm{E}-03$ & 647.05 \\
\hline NM_001002758 & PRY2 & PTPN13-like, Y-linked 2 & 1.47 & $3.99 \mathrm{E}-03$ & 650.48 \\
\hline NM_001135654 & PABPC4 & $\begin{array}{l}\text { Poly(A) binding protein, cytoplasmic } 4 \\
\text { (inducible form) }\end{array}$ & 1.31 & $4.01 \mathrm{E}-03$ & 651.26 \\
\hline NM_014030 & GIT1 & $\begin{array}{l}\text { G protein-coupled receptor kinase } \\
\text { interacting ArfGAP } 1\end{array}$ & 1.17 & $4.13 \mathrm{E}-03$ & 657.53 \\
\hline NM_001083537 & FAM86B1 & $\begin{array}{l}\text { Family with sequence similarity } 86 \text {, } \\
\text { member B1 }\end{array}$ & 1.29 & $4.16 \mathrm{E}-03$ & 658.91 \\
\hline NM_001645 & APOC1 & Apolipoprotein C-I & 1.20 & $4.27 \mathrm{E}-03$ & 664.10 \\
\hline NM_003226 & TFF3 & Trefoil factor 3 (intestinal) & 1.19 & $4.29 \mathrm{E}-03$ & 664.92 \\
\hline NM_005172 & ATOH1 & Atonal homolog 1 (Drosophila) & 1.26 & $4.31 \mathrm{E}-03$ & 665.93 \\
\hline
\end{tabular}


Table II. Continued.

\begin{tabular}{|c|c|c|c|c|c|}
\hline Gene reference & Gene symbol & Name & Mean & $\begin{array}{l}\text { P-values } \\
\text { (Up) }\end{array}$ & $\begin{array}{l}\text { RP-values } \\
\quad \text { (Up) }\end{array}$ \\
\hline NM_003708 & RDH16 & Retinol dehydrogenase 16 (all-trans) & 0.92 & 4.41E-03 & 670.22 \\
\hline NM_002917 & RFNG & $\begin{array}{l}\text { RFNG O-fucosylpeptide } 3-\beta-\mathrm{N} \text { - } \\
\text { acetylglucosaminyltransferase }\end{array}$ & 1.28 & $4.56 \mathrm{E}-03$ & 677.43 \\
\hline NM_016585 & THEG & Theg homolog (mouse) & 1.19 & $4.63 \mathrm{E}-03$ & 681.11 \\
\hline NM_007058 & CAPN11 & Calpain 11 & 1.51 & 4.73E-03 & 684.84 \\
\hline NM_003759 & SLC4A4 & $\begin{array}{l}\text { Solute carrier family } 4 \text {, sodium bicarbonate } \\
\text { co-transporter, member } 4\end{array}$ & 1.19 & $4.74 \mathrm{E}-03$ & 685.17 \\
\hline NM_020299 & AKR1B10 & $\begin{array}{l}\text { Aldo-keto reductase family } 1 \text {, } \\
\text { member B10 (aldose reductase) }\end{array}$ & 1.17 & 4.77E-03 & 686.57 \\
\hline NM_032133 & MYCBPAP & MYCBP-associated protein & 0.92 & $4.95 \mathrm{E}-03$ & 693.39 \\
\hline NM_001631 & ALPI & Alkaline phosphatase, intestinal & 1.25 & $4.98 \mathrm{E}-03$ & 695.09 \\
\hline NM_002486 & NCBP1 & Nuclear cap binding protein subunit $1,80 \mathrm{kDa}$ & 1.23 & $5.09 \mathrm{E}-03$ & 699.73 \\
\hline NM_001105659 & LRRIQ3 & Leucine-rich repeats and IQ motif containing 3 & 1.18 & $5.13 \mathrm{E}-03$ & 702.05 \\
\hline NM_014276 & RBPJL & $\begin{array}{l}\text { Recombination signal binding protein } \\
\text { for immunoglobulin- } \mathrm{kJ} \text { region-like }\end{array}$ & 1.15 & $5.29 \mathrm{E}-03$ & 708.75 \\
\hline NM_015461 & ZNF521 & Zinc finger protein 521 & 0.91 & $5.35 \mathrm{E}-03$ & 711.10 \\
\hline NM_001105662 & & Ubiquitin specific peptidase 17 & 1.21 & $5.63 \mathrm{E}-03$ & 722.91 \\
\hline NM_005068 & SIM1 & Single-minded homolog 1 (Drosophila) & 1.19 & $5.73 \mathrm{E}-03$ & 726.21 \\
\hline NM_018646 & TRPV6 & $\begin{array}{l}\text { Transient receptor potential cation channel, } \\
\text { subfamily V, member } 6\end{array}$ & 0.64 & $6.05 \mathrm{E}-03$ & 739.17 \\
\hline NM_139026 & ADAMTS13 & $\begin{array}{l}\text { ADAM metallopeptidase with } \\
\text { thrombospondin type } 1 \text { motif, } 13\end{array}$ & 0.84 & $6.31 \mathrm{E}-03$ & 749.50 \\
\hline NM_152749 & ATXN7L1 & Ataxin 7-like 1 & 0.75 & $6.31 \mathrm{E}-03$ & 749.64 \\
\hline NM_019034 & RHOF & $\begin{array}{l}\text { Ras homolog gene family, member F } \\
\text { (in filopodia) }\end{array}$ & 1.21 & $6.35 \mathrm{E}-03$ & 751.22 \\
\hline NM_017592 & MED29 & Mediator complex subunit 29 & 0.92 & $6.38 \mathrm{E}-03$ & 752.10 \\
\hline NM_206965 & FTCD & Formiminotransferase cyclodeaminase & 1.16 & $6.40 \mathrm{E}-03$ & 752.88 \\
\hline NM_020063 & BARHL2 & BarH-like homeobox 2 & 1.10 & $6.41 \mathrm{E}-03$ & 753.43 \\
\hline NM_016338 & IPO11 & Importin 11 & 0.74 & $6.51 \mathrm{E}-03$ & 756.92 \\
\hline NM_001109997 & KLHL33 & Kelch-like 33 (Drosophila) & 1.15 & $6.61 \mathrm{E}-03$ & 761.02 \\
\hline NM_004235 & KLF4 & Kruppel-like factor 4 (gut) & 0.96 & $6.64 \mathrm{E}-03$ & 762.27 \\
\hline NM_172365 & PPP1R36 & Protein phosphatase 1 , regulatory subunit 36 & 0.93 & $6.74 \mathrm{E}-03$ & 765.82 \\
\hline NM_003665 & FCN3 & $\begin{array}{l}\text { Ficolin (collagen/fibrinogen domain containing) } \\
3 \text { (Hakata antigen) }\end{array}$ & 1.23 & $6.86 \mathrm{E}-03$ & 770.05 \\
\hline NM_017910 & TRMT61B & $\begin{array}{l}\text { tRNA methyltransferase } 61 \text { homolog B } \\
\text { (S. cerevisiae) }\end{array}$ & 0.97 & 7.11E-03 & 778.71 \\
\hline NM_031459 & SESN2 & Sestrin 2 & 0.27 & $7.16 \mathrm{E}-03$ & 780.18 \\
\hline NM_203458 & NOTCH2NL & Notch 2 N-terminal like & 0.59 & $7.16 \mathrm{E}-03$ & 780.21 \\
\hline NM_002203 & ITGA2 & $\begin{array}{l}\text { Integrin, } \alpha 2(\mathrm{CD} 49 \mathrm{~B}, \alpha 2 \text { subunit of } \\
\text { VLA-2 receptor) }\end{array}$ & 1.20 & $7.16 \mathrm{E}-03$ & 780.44 \\
\hline NM_138337 & CLEC12A & C-type lectin domain family 12 , member A & 1.32 & 7.22E-03 & 782.42 \\
\hline NM_020533 & MCOLN1 & Mucolipin 1 & 0.51 & 7.33E-03 & 786.12 \\
\hline NM_022481 & ARAP3 & $\begin{array}{l}\text { ArfGAP with RhoGAP domain, } \\
\text { ankyrin repeat and PH domain } 3\end{array}$ & 1.11 & $7.42 \mathrm{E}-03$ & 789.36 \\
\hline NM_001105578 & SYCE2 & $\begin{array}{l}\text { Synaptonemal complex central element } \\
\text { protein } 2\end{array}$ & 1.13 & $7.66 \mathrm{E}-03$ & 797.43 \\
\hline NM_021969 & NR0B2 & $\begin{array}{l}\text { Nuclear receptor subfamily } 0 \text {, group B, } \\
\text { member } 2\end{array}$ & 1.16 & $7.68 \mathrm{E}-03$ & 798.17 \\
\hline NM_015852 & ZNF117 & Zinc finger protein 117 & 1.18 & $7.69 \mathrm{E}-03$ & 798.86 \\
\hline NM_023946 & LYNX1 & Ly6/neurotoxin 1 & 1.10 & $7.89 \mathrm{E}-03$ & 805.77 \\
\hline NM_001039887 & PROSER3 & Chromosome 19 open reading frame 55 & 1.17 & 7.94E-03 & 807.24 \\
\hline NM_015184 & PLCL2 & Phospholipase C-like 2 & 1.06 & $8.02 \mathrm{E}-03$ & 809.76 \\
\hline
\end{tabular}


Table II. Continued.

\begin{tabular}{|c|c|c|c|c|c|}
\hline Gene reference & Gene symbol & Name & Mean & $\begin{array}{l}\text { P-values } \\
\text { (Up) }\end{array}$ & $\begin{array}{l}\text { RP-values } \\
\text { (Up) }\end{array}$ \\
\hline NM_004938 & DAPK1 & Death-associated protein kinase 1 & 0.54 & $8.06 \mathrm{E}-03$ & 811.54 \\
\hline NM_004755 & RPS6KA5 & $\begin{array}{l}\text { Ribosomal protein S6 kinase, } \\
90 \mathrm{kDa} \text {, polypeptide } 5\end{array}$ & 1.04 & $8.21 \mathrm{E}-03$ & 816.35 \\
\hline NM_001007532 & STH & Saitohin & 1.17 & $8.24 \mathrm{E}-03$ & 817.51 \\
\hline NM_002613 & PDPK1 & $\begin{array}{l}\text { 3-Phosphoinositide-dependent protein } \\
\text { kinase-1 }\end{array}$ & 1.10 & $8.34 \mathrm{E}-03$ & 820.46 \\
\hline NM_006620 & HBS1L & HBS1-like (S. cerevisiae) & 1.04 & $8.46 \mathrm{E}-03$ & 824.24 \\
\hline NM_003382 & VIPR2 & Vasoactive intestinal peptide receptor 2 & 0.77 & $8.55 \mathrm{E}-03$ & 826.94 \\
\hline NM_203486 & DLL3 & -like 3 (Drosophila) & 1.07 & $8.56 \mathrm{E}-03$ & 827.15 \\
\hline NM_018010 & IFT57 & $\begin{array}{l}\text { Intraflagellar transport } 57 \text { homolog } \\
\text { (Chlamydomonas) }\end{array}$ & 0.92 & $8.74 \mathrm{E}-03$ & 833.66 \\
\hline NM_001135816 & CXORF56 & $\begin{array}{l}\text { C1QTNF9B antisense RNA } 1 \\
\text { (non-protein coding) }\end{array}$ & 0.87 & $8.76 \mathrm{E}-03$ & 834.30 \\
\hline NM_033133 & $\mathrm{CNP}$ & $\begin{array}{l}\text { 2',3'-Cyclic nucleotide } \\
\text { 3' phosphodiesterase }\end{array}$ & 1.02 & $8.84 \mathrm{E}-03$ & 836.32 \\
\hline NM_005199 & CHRNG & Cholinergic receptor, nicotinic, $\gamma$ & 0.98 & $9.01 \mathrm{E}-03$ & 841.20 \\
\hline NM_182765 & HECTD2 & HECT domain containing 2 & 0.79 & $9.12 \mathrm{E}-03$ & 844.85 \\
\hline NM_001145290 & SLC37A2 & $\begin{array}{l}\text { Solute carrier family } 37 \text { (glycerol-3- } \\
\text { phosphate transporter), member } 2\end{array}$ & 0.90 & $9.15 \mathrm{E}-03$ & 845.70 \\
\hline NM_001195252 & APTX & Aprataxin & 1.05 & $9.31 \mathrm{E}-03$ & 850.77 \\
\hline NM_001251964 & TP53AIP1 & $\begin{array}{l}\text { Tumor protein p53-regulated } \\
\text { apoptosis inducing protein } 1\end{array}$ & 1.26 & $9.35 \mathrm{E}-03$ & 851.82 \\
\hline NM_198270 & NHS & $\begin{array}{l}\text { Nance-Horan syndrome (congenital } \\
\text { cataracts and dental anomalies) }\end{array}$ & 1.13 & $9.53 \mathrm{E}-03$ & 857.71 \\
\hline NM_000578 & SLC11A1 & $\begin{array}{l}\text { Solute carrier family } 11 \text { (proton-coupled } \\
\text { divalent metal ion transporters), member } 1\end{array}$ & 1.06 & $9.63 \mathrm{E}-03$ & 859.97 \\
\hline NM_002139 & RBMX & RNA binding motif protein, $\mathrm{X}$-linked & 1.06 & $9.65 \mathrm{E}-03$ & 860.47 \\
\hline NM_000435 & NOTCH3 & Notch 3 & 1.10 & $9.71 \mathrm{E}-03$ & 862.14 \\
\hline NM_033066 & MPP4 & $\begin{array}{l}\text { Membrane protein, palmitoylated } 4 \\
\text { (MAGUK p55 subfamily member } 4 \text { ) }\end{array}$ & 1.12 & $9.87 \mathrm{E}-03$ & 867.43 \\
\hline
\end{tabular}

B, Downregulated genes

\begin{tabular}{lllllc}
\hline Gene reference & Gene symbol & \multicolumn{1}{c}{ Name } & Mean & $\begin{array}{c}\text { P-values } \\
\text { (Down) }\end{array}$ & $\begin{array}{c}\text { RP-values } \\
\text { (Down) }\end{array}$ \\
\hline AJ298317 & MUC5AC & $\begin{array}{l}\text { Mucin 5AC, oligomeric mucus/ } \\
\text { gel-forming }\end{array}$ & -2.54 & $8.43 \mathrm{E}-06$ & 112.88 \\
AF547222 & LOC280665 & $\begin{array}{l}\text { Anti-CNG } \alpha 1 \text { cation channel } \\
\text { translation product-like }\end{array}$ & -2.76 & $1.31 \mathrm{E}-05$ & 123.92 \\
& NQO2 & NAD(P)H dehydrogenase, quinone 2 & -2.48 & $3.75 \mathrm{E}-05$ & 169.61 \\
AK097187 & RNF216 & Ring finger protein 216 & -2.19 & $6.09 \mathrm{E}-05$ & 198.31 \\
AK128551 & EFCAB10 & EF-hand calcium binding domain 10 & -2.10 & $1.14 \mathrm{E}-04$ & 233.55 \\
BC062748 & FASLG & Fas ligand (TNF superfamily, member 6) & -1.61 & $2.15 \mathrm{E}-04$ & 274.72 \\
NM_000639 & ADM & Adrenomedullin & -1.48 & $3.43 \mathrm{E}-04$ & 311.18 \\
NM_001124 & FAS & Fas (TNF receptor superfamily, member 6) & -1.68 & $4.22 \mathrm{E}-04$ & 329.27 \\
NM_000043 & EXD3 & Exonuclease 3'-5' domain containing 3 & -2.04 & $5.19 \mathrm{E}-04$ & 349.20 \\
BC065002 & CD8B & CD8b molecule & -1.24 & $6.82 \mathrm{E}-04$ & 378.73 \\
NM_004931 & PBOV1 & Prostate and breast cancer overexpressed 1 & -1.17 & $7.31 \mathrm{E}-04$ & 386.63 \\
NM_021635 & COL5A1 & Collagen, type V, 1 1 & -1.67 & $8.08 \mathrm{E}-04$ & 398.60 \\
NM_000093 & MAT1A & Methionine adenosyltransferase I, $\alpha$ & -1.67 & $8.43 \mathrm{E}-04$ & 403.54 \\
NM_000429 & & & & &
\end{tabular}


Table II. Continued.

\begin{tabular}{|c|c|c|c|c|c|}
\hline Gene reference & Gene symbol & Name & Mean & $\begin{array}{l}\text { P-values } \\
\text { (Down) }\end{array}$ & $\begin{array}{c}\text { RP-values } \\
\text { (Down) }\end{array}$ \\
\hline NM_000033 & $\mathrm{ABCD} 1$ & $\begin{array}{l}\text { ATP-binding cassette, sub-family D } \\
\text { (ALD), member } 1\end{array}$ & -1.69 & 8.92E-04 & 411.33 \\
\hline NM_000125 & ESR1 & Estrogen receptor 1 & -1.67 & $8.95 \mathrm{E}-04$ & 411.64 \\
\hline NM_000808 & GABRA3 & $\begin{array}{l}\gamma \text {-Aminobutyric acid (GABA) } \\
\text { A receptor, } \alpha 3\end{array}$ & -1.60 & $9.27 \mathrm{E}-04$ & 415.96 \\
\hline NM_000595 & LTA & $\begin{array}{l}\text { Lymphotoxin- } \alpha \text { (TNF superfamily, } \\
\text { member 1) }\end{array}$ & -1.63 & $9.95 \mathrm{E}-04$ & 427.69 \\
\hline NM_000197 & HSD17B3 & Hydroxysteroid (17- $\beta$ ) dehydrogenase 3 & -1.67 & $1.04 \mathrm{E}-03$ & 432.79 \\
\hline NM_001037442 & RUFY3 & RUN and FYVE domain containing 3 & -1.54 & $1.05 \mathrm{E}-03$ & 434.60 \\
\hline NM_000545 & HNF1A & HNF1 homeobox A & -1.64 & $1.07 \mathrm{E}-03$ & 437.31 \\
\hline NM_001005490 & OR6C74 & $\begin{array}{l}\text { Olfactory receptor, family } 6 \text {, } \\
\text { subfamily } \mathrm{C} \text {, member } 74\end{array}$ & -1.59 & $1.09 \mathrm{E}-03$ & 439.40 \\
\hline NM_001031848 & SERPINB8 & $\begin{array}{l}\text { Serpin peptidase inhibitor, clade B } \\
\text { (ovalbumin), member } 8\end{array}$ & -1.54 & $1.15 \mathrm{E}-03$ & 447.15 \\
\hline NM_000612 & IGF2 & $\begin{array}{l}\text { Insulin-like growth factor } 2 \\
\text { (somatomedin A) }\end{array}$ & -1.63 & $1.16 \mathrm{E}-03$ & 448.01 \\
\hline NM_000517 & HBA2 & Hemoglobin, $\alpha 2$ & -1.64 & $1.19 \mathrm{E}-03$ & 451.63 \\
\hline NM_001130861 & CLDN5 & Claudin 5 & -1.44 & $1.24 \mathrm{E}-03$ & 458.33 \\
\hline NM_001004688 & OR2M2 & $\begin{array}{l}\text { Olfactory receptor, family } 2 \text {, } \\
\text { subfamily } \mathrm{M} \text {, member } 2\end{array}$ & -1.59 & $1.24 \mathrm{E}-03$ & 458.57 \\
\hline NM_001030004 & HNF4A & Hepatocyte nuclear factor $4, \alpha$ & -1.56 & $1.26 \mathrm{E}-03$ & 460.62 \\
\hline NM_001033952 & CALCA & Calcitonin-related polypeptide $\alpha$ & -1.54 & $1.26 \mathrm{E}-03$ & 461.21 \\
\hline NM_001010870 & TDRD6 & Tudor domain containing 6 & -1.58 & $1.32 \mathrm{E}-03$ & 466.23 \\
\hline NM_001018025 & MTCP1 & Mature $\mathrm{T}$ cell proliferation 1 & -1.57 & $1.41 \mathrm{E}-03$ & 475.20 \\
\hline NM_001012967 & DDX60L & $\begin{array}{l}\text { DEAD (Asp-Glu-Ala-Asp) } \\
\text { box polypeptide } 60 \text {-like }\end{array}$ & -1.57 & $1.41 \mathrm{E}-03$ & 475.20 \\
\hline NM_001085 & SERPINA3 & $\begin{array}{l}\text { Serpin peptidase inhibitor, clade A } \\
(\alpha-1 \text { antiproteinase, antitrypsin), } \\
\text { member } 3\end{array}$ & -1.49 & $1.42 \mathrm{E}-03$ & 476.63 \\
\hline NM_000633 & BCL2 & B-cell CLL/lymphoma 2 & -1.63 & $1.45 \mathrm{E}-03$ & 479.53 \\
\hline NM_001037666 & GATSL3 & GATS protein-like 3 & -1.52 & $1.52 \mathrm{E}-03$ & 486.52 \\
\hline NM_001165 & BIRC3 & Baculoviral IAP repeat containing 3 & -1.42 & $1.58 \mathrm{E}-03$ & 491.86 \\
\hline NM_002247 & KCNMA1 & $\begin{array}{l}\text { Potassium large conductance calcium- } \\
\text { activated channel, subfamily } \mathrm{M} \text {, } \\
\alpha \text { member } 1\end{array}$ & -1.33 & $1.94 \mathrm{E}-03$ & 521.16 \\
\hline NM_173625 & C17ORF78 & Chromosome 17 open reading frame 78 & -1.01 & $1.95 \mathrm{E}-03$ & 521.61 \\
\hline NM_001124759 & FRG2C & FSHD region gene 2 family, member $\mathrm{C}$ & -1.44 & $2.00 \mathrm{E}-03$ & 524.95 \\
\hline NM_001080453 & INTS1 & Integrator complex subunit 1 & -1.51 & $2.00 \mathrm{E}-03$ & 524.88 \\
\hline NM_004613 & TGM2 & $\begin{array}{l}\text { Transglutaminase } 2 \text { (C polypeptide, } \\
\text { protein-glutamine- } \gamma \text {-glutamyltransferase) }\end{array}$ & -1.24 & $2.14 \mathrm{E}-03$ & 536.10 \\
\hline NM_001044392 & MUC1 & Mucin 1, cell surface-associated & -1.51 & $2.31 \mathrm{E}-03$ & 548.26 \\
\hline NM_001195127 & WI2-2373I1.2 & Forkhead box L1-like & -1.39 & $2.41 \mathrm{E}-03$ & 556.59 \\
\hline NM_001243042 & HLA-C & Major histocompatibility complex, class I, C & -1.38 & $2.43 \mathrm{E}-03$ & 558.50 \\
\hline NM_001083602 & PTCH1 & Patched 1 & -1.49 & $2.58 \mathrm{E}-03$ & 570.46 \\
\hline NM_207352 & CYP4V2 & $\begin{array}{l}\text { Cytochrome P450, family } 4 \text {, } \\
\text { subfamily V, polypeptide } 2\end{array}$ & -0.86 & 2.71E-03 & 579.03 \\
\hline NR_029392 & KRT16P2 & Keratin 16 pseudogene 2 & -0.54 & $2.97 \mathrm{E}-03$ & 594.00 \\
\hline NM_001172646 & PLCB4 & Phospholipase C, $\beta 4$ & -1.39 & 3.03E-03 & 598.52 \\
\hline NM_002089 & CXCL2 & Chemokine (C-X-C motif) ligand 2 & -1.34 & $3.39 \mathrm{E}-03$ & 620.43 \\
\hline NM_001496 & GFRA3 & GDNF family receptor $\alpha 3$ & -1.38 & $3.40 \mathrm{E}-03$ & 620.75 \\
\hline NM_001668 & ARNT & Aryl hydrocarbon receptor nuclear translocator & -1.37 & $3.42 \mathrm{E}-03$ & 622.12 \\
\hline NM_021151 & CROT & Carnitine O-octanoyltransferase & -1.18 & $3.47 \mathrm{E}-03$ & 624.70 \\
\hline
\end{tabular}


Table II. Continued.

\begin{tabular}{|c|c|c|c|c|c|}
\hline Gene reference & Gene symbol & Name & Mean & $\begin{array}{l}\text { P-values } \\
\text { (Down) }\end{array}$ & $\begin{array}{c}\text { RP-values } \\
\text { (Down) }\end{array}$ \\
\hline NM_001949 & E2F3 & E2F transcription factor 3 & -1.36 & $3.53 \mathrm{E}-03$ & 628.70 \\
\hline NM_002307 & LGALS7 & Lectin, galactoside-binding, soluble, 7 & -1.32 & $3.56 \mathrm{E}-03$ & 630.07 \\
\hline NM_001704 & BAI3 & Brain-specific angiogenesis inhibitor 3 & -1.37 & $3.57 \mathrm{E}-03$ & 630.78 \\
\hline NM_001978 & DMTN & $\begin{array}{l}\text { Erythrocyte membrane protein } \\
\text { band } 4.9 \text { (dematin) }\end{array}$ & -1.35 & $3.62 \mathrm{E}-03$ & 633.47 \\
\hline NM_183001 & SHC1 & $\begin{array}{l}\text { SHC (Src homology } 2 \text { domain containing) } \\
\text { transforming protein } 1\end{array}$ & -0.90 & $3.64 \mathrm{E}-03$ & 634.32 \\
\hline NM_001185156 & IL24 & Interleukin 24 & -1.39 & $3.71 \mathrm{E}-03$ & 637.18 \\
\hline NM_004048 & $\mathrm{B} 2 \mathrm{M}$ & $\beta$-2-microglobulin & -1.27 & $3.73 \mathrm{E}-03$ & 637.88 \\
\hline NM_001004456 & OR1M1 & $\begin{array}{l}\text { Olfactory receptor, family } 1 \text {, } \\
\text { subfamily } \mathrm{M} \text {, member } 1\end{array}$ & -1.60 & $3.85 \mathrm{E}-03$ & 644.36 \\
\hline NM_002133 & HMOX1 & Heme oxygenase (decycling) 1 & -1.33 & $3.97 \mathrm{E}-03$ & 649.35 \\
\hline NM_002457 & MUC2 & Mucin 2, oligomeric mucus/gel-forming & -1.31 & 4.02E-03 & 651.72 \\
\hline NM_001198 & PRDM1 & PR domain containing 1 , with ZNF domain & -1.39 & $4.05 \mathrm{E}-03$ & 653.14 \\
\hline NM_001136022 & NFATC4 & $\begin{array}{l}\text { Nuclear factor of activated T cells, cytoplasmic, } \\
\text { calcineurin-dependent } 4\end{array}$ & -1.43 & $4.06 \mathrm{E}-03$ & 653.68 \\
\hline NM_001454 & FOXJ1 & Horkhead box J1 & -1.38 & $4.11 \mathrm{E}-03$ & 656.34 \\
\hline NM_002006 & FGF2 & Fibroblast growth factor 2 (basic) & -1.35 & 4.11E-03 & 656.64 \\
\hline NM_177996 & EPB41L1 & Erythrocyte membrane protein band 4.1-like 1 & -0.97 & $4.19 \mathrm{E}-03$ & 659.94 \\
\hline NM_004417 & DUSP1 & Dual specificity phosphatase 1 & -1.25 & $4.38 \mathrm{E}-03$ & 669.42 \\
\hline NM_201282 & EGFR & Epidermal growth factor receptor & -0.88 & $4.53 \mathrm{E}-03$ & 676.59 \\
\hline NM_004416 & DTX1 & Deltex homolog 1 (Drosophila) & -1.25 & $4.68 \mathrm{E}-03$ & 682.88 \\
\hline NM_003128 & SPTBN1 & Spectrin, $\beta$, non-erythrocytic 1 & -1.29 & $4.75 \mathrm{E}-03$ & 685.70 \\
\hline NM_001807 & CEL & Carboxyl ester lipase (bile salt-stimulated lipase) & -1.36 & 4.94E-03 & 693.06 \\
\hline NM_207336 & ZNF467 & Zinc finger protein 467 & -0.86 & $4.95 \mathrm{E}-03$ & 693.44 \\
\hline NM_002381 & MATN3 & Matrilin 3 & -1.32 & $5.00 \mathrm{E}-03$ & 695.99 \\
\hline NM_002317 & LOX & Lysyl oxidase & -1.32 & $5.00 \mathrm{E}-03$ & 696.01 \\
\hline NM_024766 & CAMKMT & Calmodulin-lysine $\mathrm{N}$-methyltransferase & -1.15 & $5.07 \mathrm{E}-03$ & 699.15 \\
\hline NM_003667 & LGR5 & $\begin{array}{l}\text { Leucine-rich repeat containing } \mathrm{G} \\
\text { protein-coupled receptor } 5\end{array}$ & -1.29 & $5.27 \mathrm{E}-03$ & 707.84 \\
\hline NM_002535 & OAS2 & 2'-5'-Oligoadenylate synthetase $2,69 / 71 \mathrm{kDa}$ & -1.30 & $5.27 \mathrm{E}-03$ & 708.15 \\
\hline NM_145041 & TMEM106A & Transmembrane protein 106A & -1.10 & 5.27E-03 & 708.30 \\
\hline NM_003061 & SLIT1 & Slit homolog 1 (Drosophila) & -1.30 & $5.36 \mathrm{E}-03$ & 711.28 \\
\hline NM_013292 & MYLPF & $\begin{array}{l}\text { Myosin light chain, phosphorylatable, } \\
\text { fast skeletal muscle }\end{array}$ & -1.21 & $5.40 \mathrm{E}-03$ & 712.71 \\
\hline NM_004310 & $\mathrm{RHOH}$ & Ras homolog gene family, member $\mathrm{H}$ & -1.26 & $5.55 \mathrm{E}-03$ & 719.34 \\
\hline NM_002483 & CEACAM6 & $\begin{array}{l}\text { Carcinoembryonic antigen-related } \\
\text { cell adhesion molecule } 6\end{array}$ & -1.30 & $5.71 \mathrm{E}-03$ & 725.32 \\
\hline NM_005531 & IFI16 & Interferon, $\gamma$-inducible protein 16 & -1.23 & $5.87 \mathrm{E}-03$ & 732.01 \\
\hline NM_133471 & PPP1R18 & Protein phosphatase 1 , regulatory subunit 18 & -1.13 & $5.88 \mathrm{E}-03$ & 732.45 \\
\hline NM_006398 & UBD & Ubiquitin D & -1.22 & $5.89 \mathrm{E}-03$ & 732.86 \\
\hline NM_004994 & MMP9 & $\begin{array}{l}\text { Matrix metallopeptidase } 9 \text { (gelatinase B, } 92 \mathrm{kDa} \\
\text { gelatinase, } 92 \mathrm{kDa} \text { type IV collagenase) }\end{array}$ & -1.24 & $5.90 \mathrm{E}-03$ & 733.00 \\
\hline NR_003531 & MEG3 & Maternally expressed 3 (non-protein coding) & -0.79 & $5.98 \mathrm{E}-03$ & 736.40 \\
\hline NM_012171 & TSPAN17 & Tetraspanin 17 & -1.22 & $6.10 \mathrm{E}-03$ & 741.06 \\
\hline NM_032599 & FAM71F1 & Family with sequence similarity 71, member F1 & -1.14 & $6.13 \mathrm{E}-03$ & 742.39 \\
\hline NM_019074 & DLL4 & ס-like 4 (Drosophila) & -1.19 & $6.16 \mathrm{E}-03$ & 743.53 \\
\hline NM_002405 & MFNG & $\begin{array}{l}\text { MFNG O-fucosylpeptide } \\
\text { 3- } \beta \text {-N-acetylglucosaminyltransferase }\end{array}$ & -1.31 & $6.30 \mathrm{E}-03$ & 749.05 \\
\hline NM_015000 & STK38L & Serine/threonine kinase 38 -like & -1.21 & $6.32 \mathrm{E}-03$ & 750.10 \\
\hline NM_018416 & FOXJ2 & Forkhead box J2 & -1.20 & $6.36 \mathrm{E}-03$ & 751.65 \\
\hline NM_016135 & ETV7 & Ets variant 7 & -1.21 & $6.38 \mathrm{E}-03$ & 752.29 \\
\hline
\end{tabular}


Table II. Continued.

\begin{tabular}{|c|c|c|c|c|c|}
\hline Gene reference & Gene symbol & Name & Mean & $\begin{array}{l}\text { P-values } \\
\text { (Down) }\end{array}$ & $\begin{array}{c}\text { RP-values } \\
\text { (Down) }\end{array}$ \\
\hline NM_015886 & PI15 & Peptidase inhibitor 15 & -1.21 & $6.39 \mathrm{E}-03$ & 752.62 \\
\hline NM_002543 & OLR1 & $\begin{array}{l}\text { Oxidized low density lipoprotein } \\
\text { (lectin-like) receptor } 1\end{array}$ & -1.30 & $6.40 \mathrm{E}-03$ & 752.88 \\
\hline NM_005023 & PGGT1B & $\begin{array}{l}\text { Protein geranylgeranyltransferase type I, } \\
\beta \text {-subunit }\end{array}$ & -1.24 & $6.53 \mathrm{E}-03$ & 757.78 \\
\hline NM_172390 & NFATC1 & $\begin{array}{l}\text { Nuclear factor of activated T cells, } \\
\text { cytoplasmic, calcineurin-dependent } 1\end{array}$ & -1.02 & $6.57 \mathrm{E}-03$ & 759.52 \\
\hline NM_017766 & CASZ1 & Castor zinc finger 1 & -1.20 & $6.78 \mathrm{E}-03$ & 767.06 \\
\hline NM_144633 & KCNH8 & $\begin{array}{l}\text { Potassium voltage-gated channel, } \\
\text { subfamily H (eag-related), member } 8\end{array}$ & -1.12 & $6.86 \mathrm{E}-03$ & 770.19 \\
\hline NM_025125 & TMEM254 & Chromosome 10 open reading frame 57 & -1.14 & $6.87 \mathrm{E}-03$ & 770.43 \\
\hline NM_182909 & FILIP1L & Filamin A interacting protein 1-like & -0.92 & $6.89 \mathrm{E}-03$ & 771.28 \\
\hline NM_173503 & EFCAB3 & EF-hand calcium binding domain 3 & -1.02 & $6.92 \mathrm{E}-03$ & 772.10 \\
\hline NM_144673 & CMTM2 & $\begin{array}{l}\text { CKLF-like MARVEL transmembrane } \\
\text { domain containing } 2\end{array}$ & -1.12 & $6.95 \mathrm{E}-03$ & 773.54 \\
\hline NM_021819 & LMAN1L & Lectin, mannose-binding, 1-like & -1.17 & $6.95 \mathrm{E}-03$ & 773.62 \\
\hline NM_022804 & SNURF & SNRPN upstream reading frame & -1.16 & $6.99 \mathrm{E}-03$ & 775.02 \\
\hline NM_021633 & KLHL12 & Kelch-like 12 (Drosophila) & -1.17 & 7.01E-03 & 775.60 \\
\hline NM_021966 & TCL1A & $\mathrm{T}$ cell leukemia/lymphoma $1 \mathrm{~A}$ & -1.16 & 7.23E-03 & 782.50 \\
\hline NM_032637 & SKP2 & $\mathrm{S}$ phase kinase-associated protein $2(\mathrm{p} 45)$ & -1.14 & 7.27E-03 & 784.16 \\
\hline NM_022648 & TNS1 & Tensin 1 & -1.16 & 7.32E-03 & 785.88 \\
\hline NM_004213 & SLC28A1 & $\begin{array}{l}\text { Solute carrier family } 28 \\
\text { (sodium-coupled nucleoside transporter), } \\
\text { member } 1\end{array}$ & -1.27 & $7.46 \mathrm{E}-03$ & 790.45 \\
\hline NM_033088 & STRIP1 & Family with sequence similarity 40 , member A & -1.14 & 7.49E-03 & 791.43 \\
\hline NM_022304 & HRH2 & Histamine receptor $\mathrm{H} 2$ & -1.16 & $7.62 \mathrm{E}-03$ & 796.01 \\
\hline NM_021105 & PLSCR1 & Phospholipid scramblase 1 & -1.18 & $7.65 \mathrm{E}-03$ & 797.28 \\
\hline NM_024768 & EFCC1 & Coiled-coil domain containing 48 & -1.15 & $7.66 \mathrm{E}-03$ & 797.48 \\
\hline NM_006290 & TNFAIP3 & Tumor necrosis factor, $\alpha$-induced protein 3 & -1.22 & $7.68 \mathrm{E}-03$ & 798.22 \\
\hline NM_030639 & BHLHB9 & $\begin{array}{l}\text { Basic helix-loop-helix domain containing, } \\
\text { class B, } 9\end{array}$ & -1.14 & 7.69E-03 & 798.53 \\
\hline NM_004246 & GLP2R & Glucagon-like peptide 2 receptor & -1.26 & $7.79 \mathrm{E}-03$ & 802.00 \\
\hline NM_032873 & UBASH3B & $\begin{array}{l}\text { Ubiquitin-associated and } \\
\text { SH3 domain containing B }\end{array}$ & -1.14 & 7.79E-03 & 802.14 \\
\hline NM_001963 & EGF & Epidermal growth factor & -1.35 & 7.84E-03 & 803.92 \\
\hline NM_052904 & KLHL32 & Kelch-like 32 (Drosophila) & -1.13 & 7.89E-03 & 805.79 \\
\hline NM_006125 & ARHGAP6 & Rho GTPase activating protein 6 & -1.23 & 7.90E-03 & 806.11 \\
\hline NM_032772 & ZNF503 & Zinc finger protein 503 & -1.14 & $7.95 \mathrm{E}-03$ & 807.90 \\
\hline NM_024886 & C10orf95 & Chromosome 10 open reading frame 95 & -1.15 & 7.99E-03 & 809.09 \\
\hline NM_152703 & SAMD9L & Sterile $\alpha$ motif domain containing 9-like & -1.09 & $8.02 \mathrm{E}-03$ & 809.77 \\
\hline NM_032752 & ZNF496 & Zinc finger protein 496 & -1.14 & 8.03E-03 & 810.31 \\
\hline NM_138456 & BATF2 & $\begin{array}{l}\text { Basic leucine zipper transcription factor, } \\
\text { ATF-like } 2\end{array}$ & -1.13 & 8.04E-03 & 810.45 \\
\hline NM_172370 & DAOA & D-amino acid oxidase activator & -1.04 & 8.07E-03 & 811.67 \\
\hline NM_005747 & CELA3A & $\begin{array}{l}\text { Chymotrypsin-like elastase family, } \\
\text { member } 3 \mathrm{~A}\end{array}$ & -1.23 & 8.07E-03 & 811.75 \\
\hline NM_033101 & LGALS12 & Lectin, galactoside-binding, soluble, 12 & -1.14 & $8.14 \mathrm{E}-03$ & 813.87 \\
\hline NM_012224 & NEK1 & $\begin{array}{l}\text { NIMA (never in mitosis gene a)- } \\
\text { related kinase } 1\end{array}$ & -1.21 & $8.21 \mathrm{E}-03$ & 816.40 \\
\hline NM_020436 & SALL4 & Sal-like 4 (Drosophila) & -1.19 & $8.31 \mathrm{E}-03$ & 819.74 \\
\hline NM_138980 & MAPK10 & Mitogen-activated protein kinase 10 & -1.13 & 8.34E-03 & 820.62 \\
\hline NM_020896 & OSBPL5 & Oxysterol binding protein-like 5 & -1.18 & $8.41 \mathrm{E}-03$ & 822.84 \\
\hline
\end{tabular}


Table II. Continued.

\begin{tabular}{|c|c|c|c|c|c|}
\hline Gene reference & Gene symbol & Name & Mean & $\begin{array}{l}\text { P-values } \\
\text { (Down) }\end{array}$ & $\begin{array}{c}\text { RP-values } \\
\text { (Down) }\end{array}$ \\
\hline NM_052897 & MBD6 & Methyl-CpG binding domain protein 6 & -1.14 & $8.52 \mathrm{E}-03$ & 826.04 \\
\hline NM_207419 & C1QTNF8 & $\mathrm{Clq}$ and tumor necrosis factor related protein 8 & -0.82 & $8.58 \mathrm{E}-03$ & 827.94 \\
\hline NM_005933 & KMT2A & $\begin{array}{l}\text { myeloid/lymphoid or mixed-lineage leukemia } \\
\text { (trithorax homolog, Drosophila) }\end{array}$ & -1.23 & $8.59 \mathrm{E}-03$ & 828.40 \\
\hline NM_181712 & KANK4 & $\mathrm{KN}$ motif and ankyrin repeat domains 4 & -0.96 & 8.61E-03 & 828.96 \\
\hline NM_017777 & MKS1 & Meckel syndrome, type 1 & -1.20 & 8.61E-03 & 829.20 \\
\hline NM_176677 & NHLRC4 & NHL repeat containing 4 & -0.99 & 8.67E-03 & 831.05 \\
\hline NM_025130 & HKDC1 & Hexokinase domain containing 1 & -1.14 & $8.71 \mathrm{E}-03$ & 832.53 \\
\hline NM_017654 & SAMD9 & Sterile $\alpha$ motif domain containing 9 & -1.21 & 8.92E-03 & 838.42 \\
\hline NM_052864 & TIFA & $\begin{array}{l}\text { TRAF-interacting protein with } \\
\text { forkhead-associated domain }\end{array}$ & -1.14 & 8.94E-03 & 838.99 \\
\hline NM_015569 & DNM3 & Dynamin 3 & -1.21 & $8.95 \mathrm{E}-03$ & 839.17 \\
\hline NM_139047 & & Mitogen-activated protein kinase 8 & -1.12 & 8.99E-03 & 840.70 \\
\hline NM_207173 & NPSR1 & Neuropeptide $S$ receptor 1 & -0.87 & $9.03 \mathrm{E}-03$ & 841.91 \\
\hline NM_015444 & TMEM158 & $\begin{array}{l}\text { Transmembrane protein } 158 \\
\text { (gene/pseudogene) }\end{array}$ & -1.21 & $9.03 \mathrm{E}-03$ & 841.90 \\
\hline NM_017523 & XAF1 & XIAP-associated factor 1 & -1.21 & $9.10 \mathrm{E}-03$ & 844.23 \\
\hline NM_006931 & SLC2A3 & $\begin{array}{l}\text { Solute carrier family } 2 \\
\text { (facilitated glucose transporter), } \\
\text { member } 3\end{array}$ & -1.22 & $9.11 \mathrm{E}-03$ & 844.45 \\
\hline NM_019018 & FAM105A & $\begin{array}{l}\text { Family with sequence similarity } 105, \\
\text { member A }\end{array}$ & -1.19 & $9.13 \mathrm{E}-03$ & 845.15 \\
\hline NM_153042 & KDM1B & Lysine (K)-specific demethylase 1B & -1.08 & $9.18 \mathrm{E}-03$ & 846.40 \\
\hline NM_033056 & PCDH15 & Protocadherin-related 15 & -1.14 & $9.23 \mathrm{E}-03$ & 848.31 \\
\hline NM_014157 & CCDC113 & Coiled-coil domain containing 113 & -1.21 & $9.25 \mathrm{E}-03$ & 848.53 \\
\hline NM_144962 & PEBP4 & Phosphatidylethanolamine-binding protein 4 & -1.12 & $9.31 \mathrm{E}-03$ & 850.61 \\
\hline NM_145862 & CHEK2 & Checkpoint kinase 2 & -1.09 & $9.36 \mathrm{E}-03$ & 852.29 \\
\hline NM_182524 & ZNF595 & Zinc finger protein 595 & -0.93 & $9.41 \mathrm{E}-03$ & 853.59 \\
\hline NM_014858 & TMCC2 & Transmembrane and coiled-coil domain family 2 & -1.21 & $9.46 \mathrm{E}-03$ & 855.35 \\
\hline NM_144990 & SLFNL1 & Schlafen-like 1 & -1.11 & $9.47 \mathrm{E}-03$ & 855.60 \\
\hline NM_022147 & RTP4 & Receptor (chemosensory) transporter protein 4 & -1.16 & $9.49 \mathrm{E}-03$ & 856.25 \\
\hline NM_022873 & IFI6 & Interferon, $\alpha$-inducible protein 6 & -1.16 & $9.73 \mathrm{E}-03$ & 863.03 \\
\hline NM_152685 & SLC23A1 & $\begin{array}{l}\text { Solute carrier family } 23 \\
\text { (nucleobase transporters), member } 1\end{array}$ & -1.09 & $9.73 \mathrm{E}-03$ & 863.10 \\
\hline NM_152278 & TCEAL7 & Transcription elongation factor A (SII)-like 7 & -1.09 & $9.84 \mathrm{E}-03$ & 866.45 \\
\hline NM_019035 & PCDH18 & Protocadherin 18 & -1.19 & $9.95 \mathrm{E}-03$ & 869.75 \\
\hline NM_153183 & NUDT10 & $\begin{array}{l}\text { Nudix (nucleoside diphosphate linked } \\
\text { moiety X)-type motif } 10\end{array}$ & -1.07 & 9.99E-03 & 870.83 \\
\hline
\end{tabular}

Fig. 3A, treatment with this agent dose-dependently induced differentiation as assessed by ALP activity. Concordantly, this agent also induced $M T 1 G$ and $M T 2 A$ mRNA levels, in close correlation to ALP activity (Pearson $\mathrm{r}=0.993, \mathrm{p}=0.007$ for $M T 1 G$ and $\mathrm{r}=0.999$, $\mathrm{p}=0.0006$ for $M T 2 A$; Fig. 3B). To determine whether the induction of MTs has a functional role in butyrate-induced differentiation, we used siRNAs to inhibit the induction of only $M T 1 G$ (si1G.1 and si1G.2) or of all MT1 and MT2 isoforms (siMTs), as previously described (12). Fig. 3C shows that siRNA pre-treatment partially mitigated $M T 1 G$ induction after BUT treatment and markedly, also diminished the induction of $C D X 2$ (Fig. 3D), and of goblet-cell marker TFF3 (Fig. 3E). Notably, BUT treatment had no effect on mRNA levels of $M U C 2$, as has been previously reported by others (17) (data not shown). In contrast, although the enterocyte-specific markers $H S I$ and $C A I$ were markedly upregulated at $2 \mathrm{mM}$ BUT, silencing of MTs had no effect on their induction (Fig. 3F and G), or on the cell-cycle arrest mediator $C D K N 1 A / p 21$ (data not shown), whereas ALP activity was only slightly, but significantly reduced (Fig. $3 \mathrm{H}$ ).

We next treated HT-29 MOCK and $\mathrm{MT}_{1} \mathrm{G}^{+}$cells with butyrate. Notably, as depicted in Fig. 4A, whereas $C D X 2$ 
Table III. Significant functional categories of upregulated and downregulated genes.

A, Upregulated genes

\section{P-value}

7.2E-07

$2.9 \mathrm{E}-05$

$6.8 \mathrm{E}-05$

9.2E-05

$1.0 \mathrm{E}-04$

2.4E-04

Intestine

KEGG pathway

Notch signaling pathway

3.5E-05
Bonferroni

8.9E-04

$3.5 \mathrm{E}-02$

$1.7 \mathrm{E}-02$

$2.4 \mathrm{E}-02$

2.6E-02

6.0E-02

2.7E-03

\subsection{E-04}

$1.2 \mathrm{E}-02$

$1.7 \mathrm{E}-02$

$1.2 \mathrm{E}-02$

8.7E-03

$1.5 \mathrm{E}-02$

2.7E-03

3.7E-02

B, Downregulated genes

GO category

Regulation of cell death

Regulation of cell proliferation

Regulation of cell migration

KEGG pathway

Pathways in cancer

$\begin{array}{llll}5.9 \mathrm{E}-07 & 9.2 \mathrm{E}-04 & 4.6 \mathrm{E}-04 & 9.8 \mathrm{E}-04 \\ 1.8 \mathrm{E}-04 & 2.4 \mathrm{E}-01 & 1.9 \mathrm{E}-02 & 2.9 \mathrm{E}-01 \\ 2.0 \mathrm{E}-04 & 2.7 \mathrm{E}-01 & 1.9 \mathrm{E}-02 & 3.3 \mathrm{E}-01 \\ & & & \\ 1.9 \mathrm{E}-04 & 1.6 \mathrm{E}-02 & 1.6 \mathrm{E}-02 & 2.1 \mathrm{E}-01\end{array}$

GO, Gene Ontology; KEGG, Kyoto Encyclopedia of Genes and Genomes; FDR, false discovery rate.

A

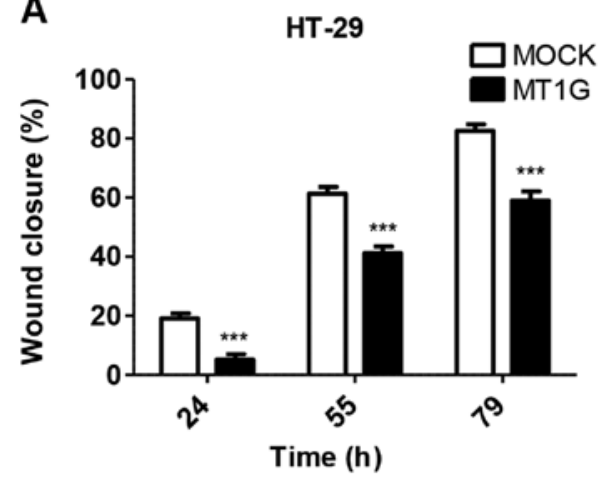

B

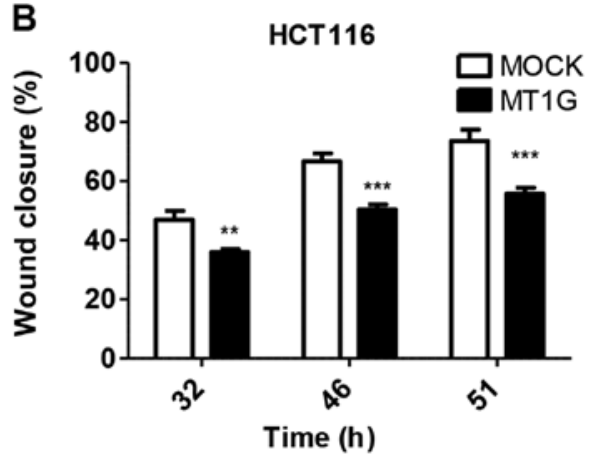

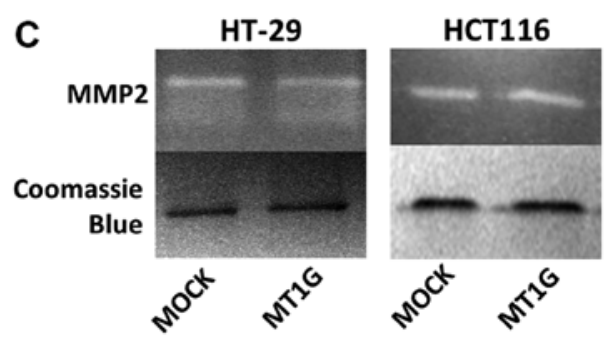

Figure 2. Wound healing 'scratch' assays in (A) HT-29 and (B) HCT116 MT1G cells showing decreased migration capacity, but no difference in MMP2 activity as measured by (C) gelatin zymography; ${ }^{*} \mathrm{p}<0.05,{ }^{* *} \mathrm{p}<0.01$ and ${ }^{* * *} \mathrm{p}<0.001$.

mRNA levels were similarly induced, MT1G overexpression markedly enhanced the induction of TFF3 (Fig. 4B), whereas it blunted that of HSI (Fig. 4C). Therefore, both silencing and overexpression of MT1G support the hypothesis that this gene favors goblet over enterocyte differentiation upon butyrate treatment of HT-29 cells. 

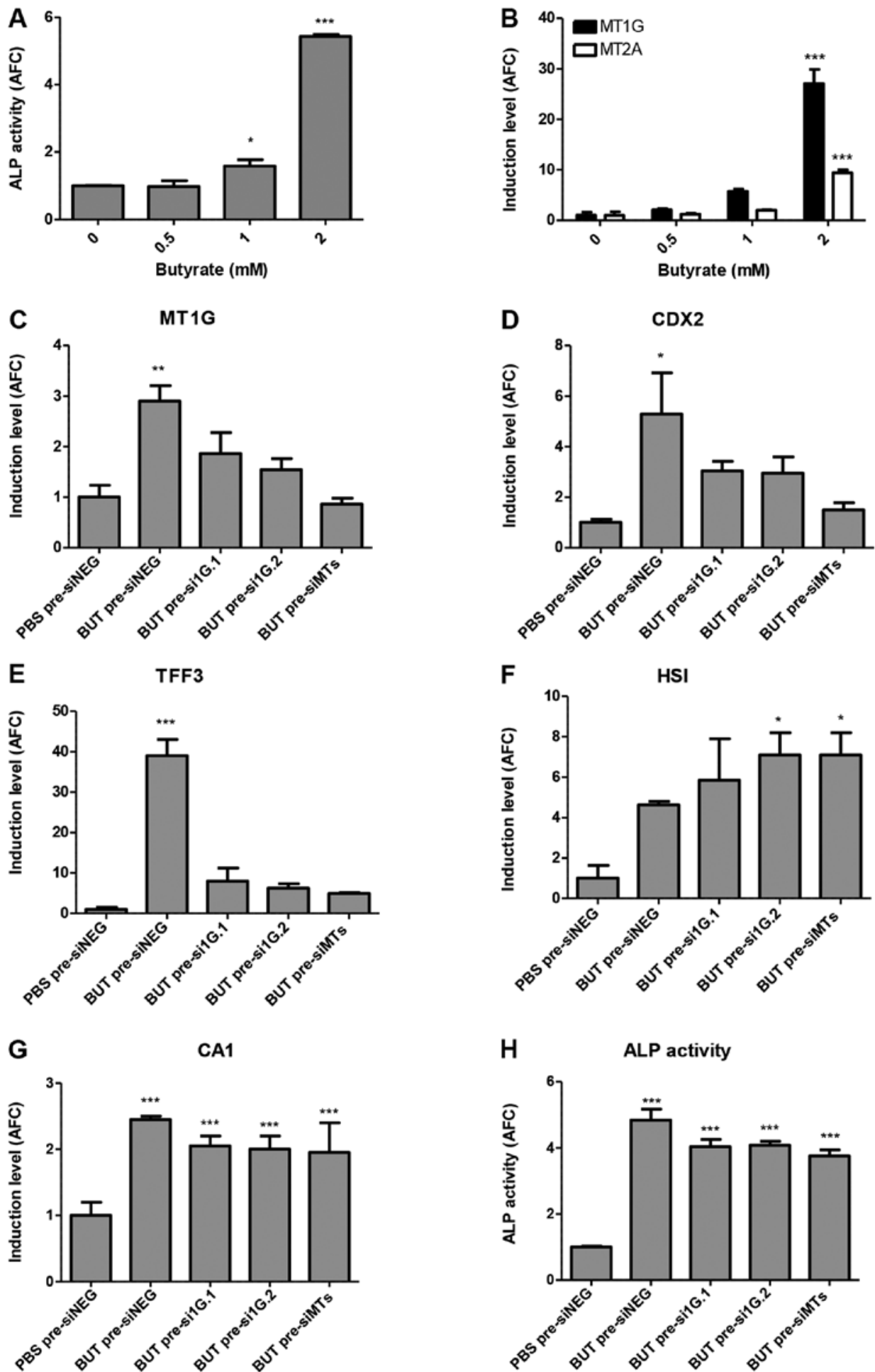

Figure 3. Butyrate mediates the differentiation of HT-29 cells. (A) Assessment of ALP enzymatic activity, $72 \mathrm{~h}$ after treatment. (B) Induction of MT1G and MT2A mRNA expression measured by qRT-PCR $72 \mathrm{~h}$ after treatment. (C-G) Expression of MT1G, CDX2, TFF3, HSI and CA1 as well as (H) ALP activity after siRNA-mediated silencing of MT1G or all MTs. AFC, average fold-change; ${ }^{*} \mathrm{p}<0.05,{ }^{* *} \mathrm{p}<0.01$ and ${ }^{* * *} \mathrm{p}<0.001$.

Involvement of $M T 1 G$ in post-confluent differentiation of HT-29 cells. Next, we studied the expression of MT1G in the post-confluent growth of HT-29 cells, where this cell line is known to differentiate poorly (20). In this setting, $M T 1 G$ mRNA was transiently induced at day 1 post-confluence, after which its expression was significantly reduced (Fig. 5A). In contrast, $C D X 2$ and enterocyte-specific genes $H S I$ and $C A I$ were transiently induced at day 3 , two days after $M T 1 G$ induction (Fig. 5B-D). Notably, TFF3 expression mirrors $M T 1 G$ expression, until day 14 when it is induced again (Fig. 5E). These time-course analyses again favored the association of MT1G induction with goblet over enterocyte differentiation. Notably, as with BUT treatment, MUC2 expression was not altered in this context (Fig. 5F). We were unable to perform 

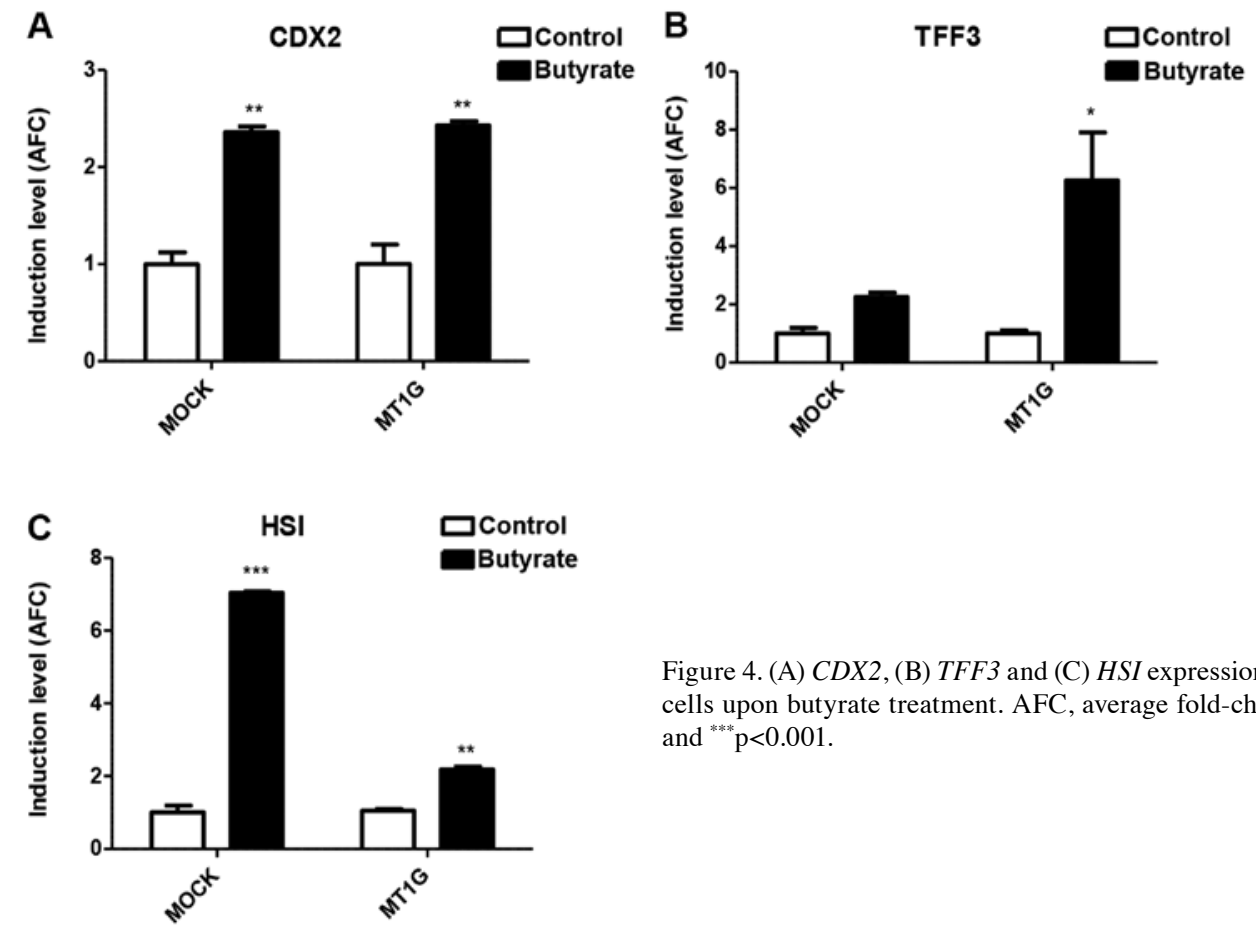

Figure 4. (A) $C D X 2$, (B) $T F F 3$ and (C) $H S I$ expression in MOCK and $\mathrm{MT}^{+} \mathrm{G}^{+}$ cells upon butyrate treatment. AFC, average fold-change; ${ }^{*} \mathrm{p}<0.05,{ }^{* *} \mathrm{p}<0.01$ and ${ }^{* * *} \mathrm{p}<0.001$.
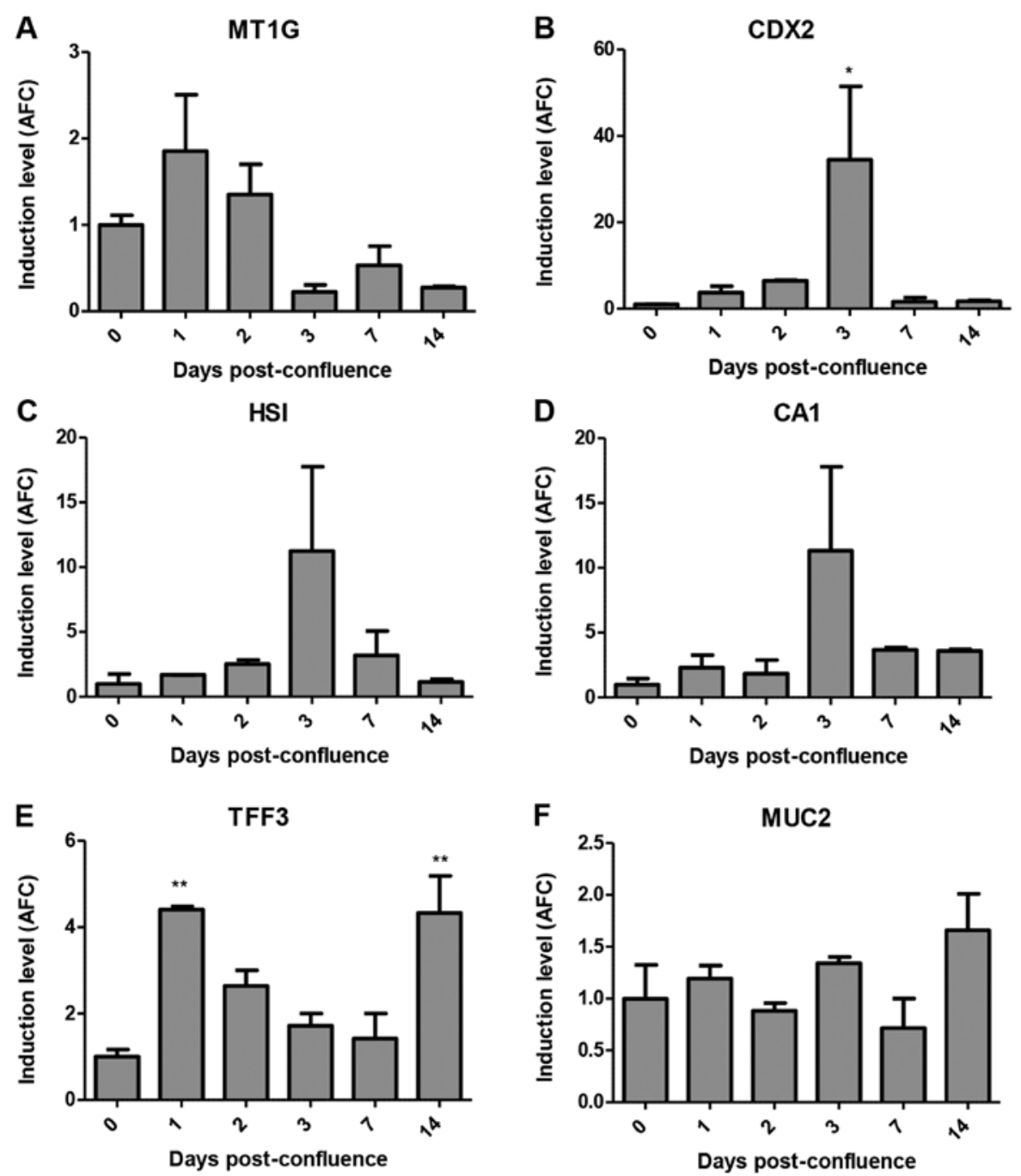

Figure 5. Expression of (A) $M T 1 G$, (B) $C D X 2$, (C) HIS, (D) CA1, (E) TFF3 and (F) MUC2 upon differentiation stimulated by post-confluent growth of HT-29 cells. AFC, average fold-change; ${ }^{*} \mathrm{p}<0.05,{ }^{* *} \mathrm{p}<0.01$ and ${ }^{* * *} \mathrm{p}<0.001$. 

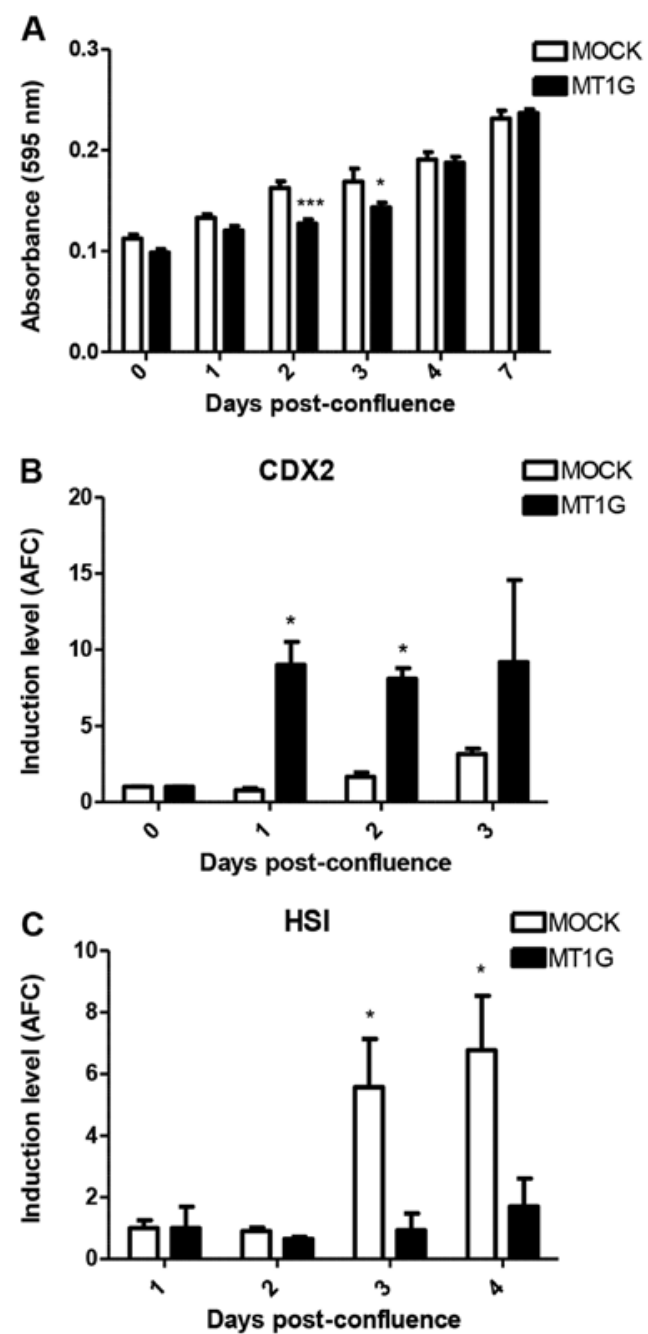

Figure 6. Effects of stable MT1G expression on post-confluent growth of HT-29 cells. (A) ALP activity. (B) CDX2 and (C) HSI expression. AFC, average fold-change; ${ }^{*} \mathrm{p}<0.05,{ }^{* *} \mathrm{p}<0.01$ and ${ }^{* * *} \mathrm{p}<0.001$.

siRNA-mediated silencing of MT1G in this setting, as cells did not survive in a totally confluent state for $>1$ day after transfection.

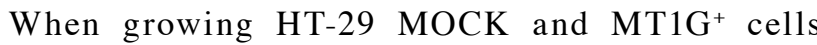
post-confluence, we noted no difference in the induction of ALP activity between these two cell lines (Fig. 6A). Notably however, in the latter, $C D X 2 \mathrm{mRNA}$ was induced at significantly higher levels (Fig. 6B) whereas HSI induction was abolished (Fig. 6C). While we noted no differences in the induction of TFF3 mRNA (data not shown), our data also implies a role for MT1G expression in counteracting enterocyte differentiation of HT-29 cells.

Labile zinc levels in butyrate-treated and post-confluent HT-29 cells. Given the close relationship between MTs and zinc biology, we analyzed the levels of intracellular labile zinc in both models of differentiation, using the zinc-specific fluorophore FZ. Notably, after $72 \mathrm{~h}$ of $2 \mathrm{mM}$ BUT treatment, FZ intensity was significantly induced in the HT-29 cells (Fig. 7A). We used TPEN treatment to chelate intracellular labile zinc before the addition of butyrate, and found that this abolished both $C D X 2$ and HSI mRNA induction (Fig. 7B and C), but had no effect on TFF3 levels (Fig. 7D). In the post-confluence model, as shown by fluorescence microscopy in Fig. 7E and by fluorimetry in Fig. 7F, FZ intensity was induced at day 2 and progressively increased thereafter. Given that TPEN exposure for $>6 \mathrm{~h}$ is toxic to HT-29 cells, we used daily 5 -h TPEN treatments to evaluate the effect of labile zinc on goblet and enterocyte markers. Notably, TFF3 mRNA expression was significantly induced at days 1-3 post-confluence in TPENtreated cells (Fig. 7G), whereas there was no effect on either CDX2 or HSI levels (not shown).

In summary, labile zinc was induced in both models of intestinal differentiation, and its chelation by TPEN treatment either inhibited enterocyte differentiation (butyrate model) or induced the expression of goblet-cell markers (post-confluency model).

\section{Discussion}

In the present study, we uncovered a new role for MT1G in altering the differentiation properties of the HT-29 cell line. We previously showed that induction of MTs by HDACi agents such as trichostatin A and sodium butyrate (BUT) is at least partly responsible for their cytostatic effects on human CRC cell lines, and that exogenous MT1G overexpression in the colorectal HCT116 cell line resulted in growth inhibition in nude mouse xenografts (12). Notably, whereas MT1G overexpression did not alter the in vivo xenograft growth rate of HT-29 cells, it markedly increased the number of goblet cells and differentiation markers of these tumors, both of the goblet and the enterocyte lineages. These effects were not readily observed in 2D culture (data not shown), suggesting that additional signals from the tumor microenvironment may be needed to fulfill this effect. The reasons for the different observed phenotypic consequences of MT1G overexpression in these two cell lines are unclear, but a possible explanation may stem from the differences in endogenous MT1G expression: HCT116 cells do not express MT1G due to promoter hypermethylation and therefore the impact of MT1G overexpression may be stronger than that in HT-29 cells, which express low, but detectable mRNA levels (8).

In an effort to understand the molecular mechanisms underlying the altered differentiation of $\mathrm{MT} \mathrm{G}^{+}$tumors, we performed mRNA expression profiling by cDNA microarrays. The expression of several genes involved in the regulation of cell differentiation was found to be altered, particularly in the Notch signaling pathway, whose inhibition is well known to stimulate goblet cell differentiation in the intestine through activation of ATOH1 (22). Notably, markers of different sets of intestinal stem cell markers were differentially dysregulated in $\mathrm{MT}_{1} \mathrm{G}^{+}$tumors, with upregulation of HOPX (expressed in quiescent stem cells) and downregulation of Lgr5 (in crypt base columnar stem cells), again suggesting altered differentiation hierarchies $(23,24)$. Further studies are warranted to explore this in further detail.

To further characterize the involvement of MT1G in colorectal differentiation, we relied on two well-studied cell culture conditions: sodium butyrate and post-confluent growth. We showed that endogenous MT1G induction was required for the induction of goblet cell markers by butyrate, and was temporally associated with such markers in the confluency 
A

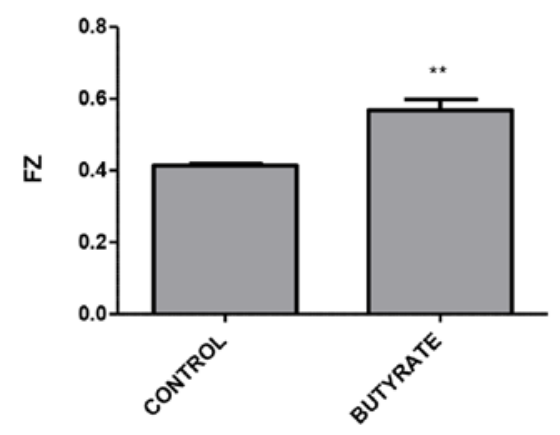

C

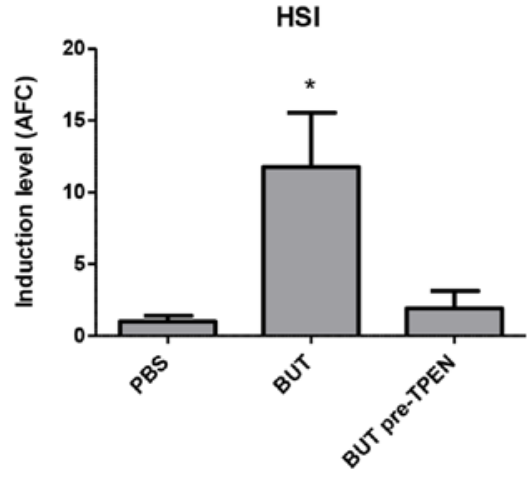

E

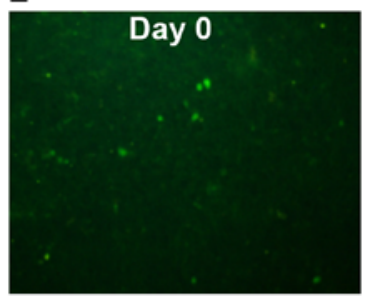

$\mathbf{F}$

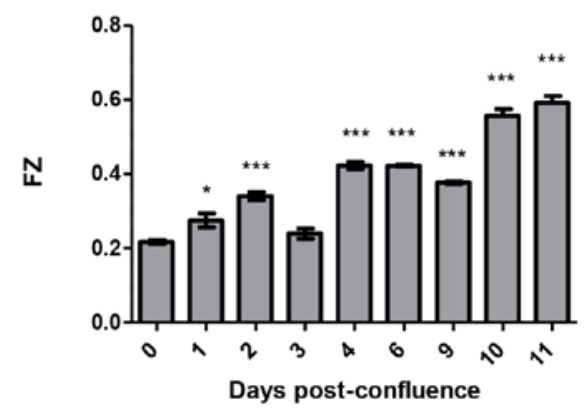

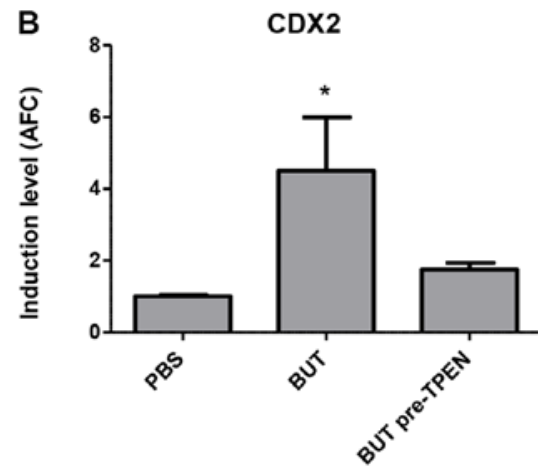

D
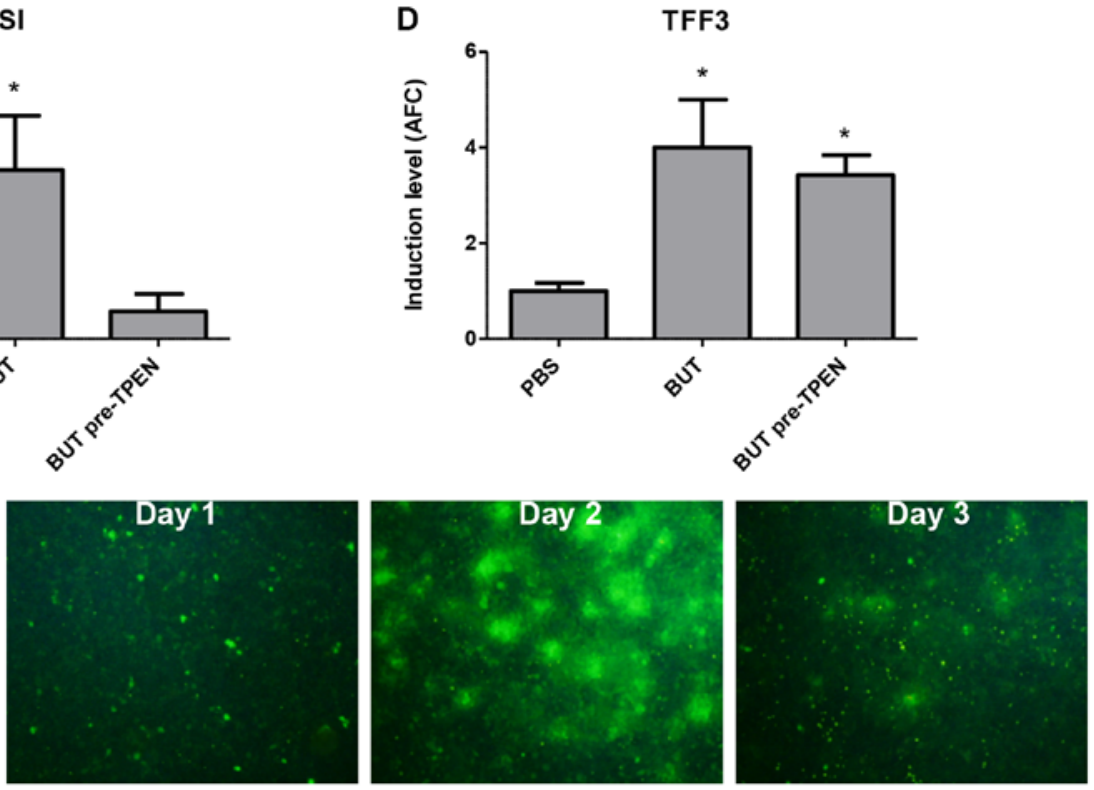

TFF3

G

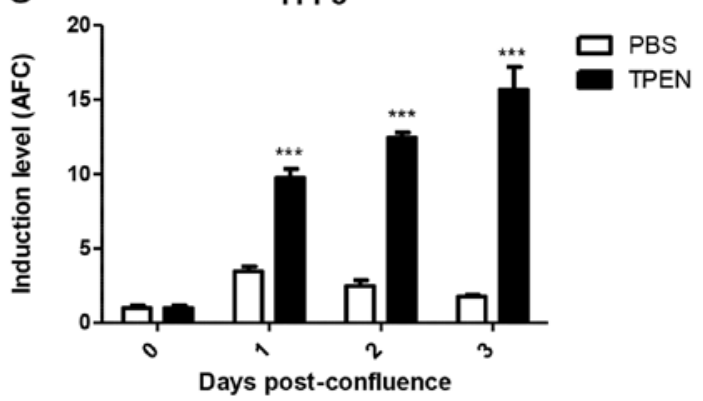

Figure 7. Labile zinc induction upon differentiation. (A) Butyrate induces intracellular labile zinc levels in HT-29 cells, as measured by fluorimetry using the Fluozin-3AM (FZ) probe. (B and C) Both CDX2 and HSI induction by butyrate are blunted by TPEN pre-treatment, whereas there is no effect on (D) TFF3 expression. (E and F) Labile zinc levels are also increased in the post-confluency differentiation model of HT-29 cells, as measured by (E) epifluorescence microscopy (F) and fluorimetry. (G) Daily doses of TPEN stimulate TFF3 expression of post-confluent cultures. AFC, average fold-change; ${ }^{*}$ p $<0.05,{ }^{* *}$ p $<0.01$ and ${ }^{* * *} \mathrm{p}<0.001$.

model. Moreover, stable exogenous MT1G overexpression favored goblet and blunted enterocyte differentiation in both models. Previous studies have shown MTs to be upregulated in vitro upon CRC differentiation (25), and demonstrated a role for MTs in modulating differentiation in different tissues, such as human salivary gland tumor cells (where MT1F overexpression resulted in slower growing and more differentiated tumors) (26), leukemic (27) neurons and glial (28), and $\mathrm{T}$ cells (29). However, to the best of our knowledge, this is the first study showing a direct functional involvement of a metallothionein isoform in CRC differentiation.
Labile zinc ions have been recognized as secondary messengers capable of transducing a wide variety of intracellular signals $(30,31)$, including differentiation (32-34). MTs can regulate labile zinc concentrations and zinc transfer to different cellular organelles (35), as well as respond to changes in intracellular zinc ions (36). We showed in the present study that labile zinc was increased during differentiation induced both by butyrate and confluency, and that this was required for enterocyte differentiation by butyrate, whereas it blunted goblet marker induction in post-confluency. While the reason behind the differences observed in both models are unclear, 
the overall effects of zinc induction favor an enterocyte over goblet differentiation. Notably, although labile zinc increases have already been reported to occur during butyrate-mediated differentiation of the HT-29 cell line and have been associated to defined stages of the cell cycle (37), in the present study, we reported for the first time a functional consequence of labile zinc induction in this process. Previous studies in other tissues have shown that MTs transiently translocate to the nucleus during early phases of differentiation to release the zinc ions necessary for zinc-dependent transcription factors to execute the differentiation programs of adipocytes and myoblasts $(38,39)$. Although we previously showed that MTs in HT-29 are localized to the cytoplasm (8), we were not able to detect a nuclear shift in either of the differentiation models that we used in the present study (data not shown), although this possibility should be studied in further detail.

Taking into account our results, we hypothesize that MT1G induction during differentiation may play a role in the chelation and re-distribution of intracellular labile zinc, perhaps modulating the activity of zinc-requiring transcription factors and enzymes, and stimulating the differentiation program of colorectal cells. In vitro, our results showed that MT1G favors a goblet over enterocyte differentiation, although our mouse xenografts assays suggest that in vivo the differentiation into enterocytes is also stimulated, perhaps as a compensatory mechanism or in a non-cell autonomous manner. The precise mechanisms whereby this occurs and the participation of MT1G (and other MTs) in labile zinc redistribution during differentiation need to be studied in further detail. Moreover, tumor classifications based on gene signatures associated with different cell types suggest that tumors of the more differentiated 'goblet-' or 'enterocyte-like' subtypes have a better prognosis than undifferentiated 'stem-like' subtype, as well as different responses to therapeutic agents. Therefore, better understanding of the molecular mechanisms that govern the differentiation processes of tumor cells may be of clinical relevance.

Overall, in the present study, we unveiled a pro-differentiation effect of MT1G on various CRC cells, thus proposing a new mechanism whereby MT1G may act as a tumor suppressor in this tumor type. Moreover, we established a functional consequence of transient increases in labile zinc upon differentiation stimuli, and support the need of further studies relating zinc signaling and differentiation, that may ultimately underlie tumor cell phenotypes and response to therapies.

\section{Acknowledgements}

The present study was funded by the Consejo Nacional de Investigaciones Científicas y Técnicas (CONICET) (PIP no. 845-10 to M.B.), the Agencia Nacional de Promoción Científica y Tecnológica (ANPCyT) (IP-PAE 2007, to J.M.), the Fundación Cáncer, the Fundación P. Mosoteguy, the Fundación Sales, and the Fundación María Calderón de la Barca, Buenos Aires, Argentina.

\section{References}

1. Torre LA, Bray F, Siegel RL, Ferlay J, Lortet-Tieulent J and Jemal A: Global cancer statistics, 2012. CA Cancer J Clin 65: $87-108,2015$
2. Dalerba P, Kalisky T, Sahoo D, Rajendran PS, Rothenberg ME, Leyrat AA, Sim S, Okamoto J, Johnston DM, Qian D, et al: Single-cell dissection of transcriptional heterogeneity in human colon tumors. Nat Biotechnol 29: 1120-1127, 2011.

3. Sadanandam A, Lyssiotis CA, Homicsko K, Collisson EA, Gibb WJ, Wullschleger S, Ostos LC, Lannon WA, Grotzinger C, Del Rio M, et al: A colorectal cancer classification system that associates cellular phenotype and responses to therapy. Nat Med 19: 619-625, 2013.

4. Pedersen MO, Larsen A, Stoltenberg M and Penkowa M: The role of metallothionein in oncogenesis and cancer prognosis. Prog Histochem Cytochem 44: 29-64, 2009.

5. Eckschlager T, Adam V, Hrabeta J, Figova K and Kizek R: Metallothioneins and cancer. Curr Protein Pept Sci 10: 360-375, 2009.

6. Dziegiel P, Pula B, Kobierzycki C, Stasiolek M and PodhorskaOkolow M: Metallothioneins in normal and cancer cells. Adv Anat Embryol Cell Biol 218: 1-117, 2016.

7. Gumulec J, Raudenska M, Adam V, Kizek R and Masarik M: Metallothionein - immunohistochemical cancer biomarker: A meta-analysis. PLoS One 9: e85346, 2014.

8. Arriaga JM, Levy EM, Bravo AI, Bayo SM, Amat M, Aris M, Hannois A, Bruno L, Roberti MP, Loria FS, et al: Metallothionein expression in colorectal cancer: Relevance of different isoforms for tumor progression and patient survival. Hum Pathol 43: 197-208, 2012.

9. Arriaga JM, Bravo IA, Bruno L, Morales Bayo S, Hannois A, Sanchez Loria F, Pairola F, Huertas E, Roberti MP, Rocca YS, et al: Combined metallothioneins and p53 proteins expression as a prognostic marker in patients with Dukes stage B and C colorectal cancer. Hum Pathol 43: 1695-1703, 2012.

10. Janssen AM, van Duijn W, Oostendorp-Van De Ruit MM, Kruidenier L, Bosman CB, Griffioen G, Lamers CB, van Krieken JH, van De Velde CJ and Verspaget HW: Metallothionein in human gastrointestinal cancer. J Pathol 192: 293-300, 2000

11. Bianchini M, Levy E, Zucchini C, Pinski V, Macagno C, De Sanctis P, Valvassori L, Carinci P and Mordoh J: Comparative study of gene expression by cDNA microarray in human colorectal cancer tissues and normal mucosa. Int J Oncol 29: 83-94, 2006.

12. Arriaga JM, Greco A, Mordoh J and Bianchini M: Metallothionein $1 \mathrm{G}$ and zinc sensitize human colorectal cancer cells to chemotherapy. Mol Cancer Ther 13: 1369-1381, 2014.

13. Cleveland WS, Devlin SJ and Grosse E: Regression by local fitting: Methods, properties, and computational algorithm. J Econom 37: 87-114, 1988

14. Yang YH, Dudoit S, Luu P, Lin DM, Peng V, Ngai J and Speed TP: Normalization for cDNA microarray data: A robust composite method addressing single and multiple slide systematic variation. Nucleic Acids Res 30: e15, 2002.

15. Dennis G Jr, Sherman BT, Hosack DA, Yang J, Gao W, Lane HC and Lempicki RA: DAVID: Database for Annotation, Visualization, and Integrated Discovery. Genome Biol 4: 3, 2003.

16. Huang W, Sherman BT and Lempicki RA: Systematic and integrative analysis of large gene lists using DAVID bioinformatics resources. Nat Protoc 4: 44-57, 2009.

17. Velcich A, Palumbo L, Jarry A, Laboisse C, Racevskis J and Augenlicht L: Patterns of expression of lineage-specific markers during the in vitro-induced differentiation of HT29 colon carcinoma cells. Cell Growth Differ 6: 749-757, 1995.

18. Troeberg L and Nagase H: Zymography of metalloproteinases. Curr Protoc Protein Sci 21: Unit 21.15, 2004.

19. Augeron C and Laboisse CL: Emergence of permanently differentiated cell clones in a human colonic cancer cell line in culture after treatment with sodium butyrate. Cancer Res 44: 3961-3969, 1984.

20. Zweibaum A, Pinto M, Chevalier G, Dussaulx E, Triadou N, Lacroix B, Haffen K, Brun JL and Rousset M: Enterocytic differentiation of a subpopulation of the human colon tumor cell line HT-29 selected for growth in sugar-free medium and its inhibition by glucose. J Cell Physiol 122: 21-29, 1985.

21. Chung YS, Song IS, Erickson RH, Sleisenger MH and Kim YS: Effect of growth and sodium butyrate on brush border membrane-associated hydrolases in human colorectal cancer cell lines. Cancer Res 45: 2976-2982, 1985.

22. VanDussen KL, Carulli AJ, Keeley TM, Patel SR, Puthoff BJ, Magness ST, Tran IT, Maillard I, Siebel C, Kolterud Å, et al: Notch signaling modulates proliferation and differentiation of intestinal crypt base columnar stem cells. Development 139: 488-497, 2012. 
23. Barker N, Ridgway RA, van Es JH, van de Wetering M, Begthel $\mathrm{H}$ van den Born M, Danenberg E, Clarke AR, Sansom OJ and Clevers H: Crypt stem cells as the cells-of-origin of intestinal cancer. Nature 457: 608-611, 2009.

24. Takeda N, Jain R, LeBoeuf MR, Wang Q, Lu MM and Epstein JA: Interconversion between intestinal stem cell populations in distinct niches. Science 334: 1420-1424, 2011.

25. Vecchini F, Pringault E, Billiar TR, Geller DA, Hausel P and Felley-Bosco E: Decreased activity of inducible nitric oxide synthase type 2 and modulation of the expression of glutathione $S$-transferase $\alpha$, bcl-2, and metallothioneins during the differentiation of CaCo-2 cells. Cell Growth Differ 8: 261-268, 1997.

26. Hecht D, Jung D, Prabhu VV, Munson PJ, Hoffman MP and Kleinman HK: Metallothionein promotes laminin-1-induced acinar differentiation in vitro and reduces tumor growth in vivo. Cancer Res 62: 5370-5374, 2002.

27. Maghdooni Bagheri P, Govaerts I and De Ley M: Role of metallothionein in differentiation of leukemia cells. Mol Biol Rep 38: 3017-3022, 2011.

28. Nishikawa M, Mori H and Hara M: Reduced zinc cytotoxicity following differentiation of neural stem/progenitor cells into neurons and glial cells is associated with upregulation of metallothioneins. Environ Toxicol Pharmacol 39: 1170-1176, 2015.

29. Wu C, Pot C, Apetoh L, Thalhamer T, Zhu B, Murugaiyan G Xiao S, Lee Y, Rangachari M, Yosef N, et al: Metallothioneins negatively regulate IL-27-induced type 1 regulatory T cell differentiation. Proc Natl Acad Sci USA 110: 7802-7807, 2013.

30. Murakami M and Hirano T: Intracellular zinc homeostasis and zinc signaling. Cancer Sci 99: 1515-1522, 2008.
31. Yamasaki S, Sakata-Sogawa K, Hasegawa A, Suzuki T, Kabu K, Sato E, Kurosaki T, Yamashita S, Tokunaga M, Nishida K, et al: Zinc is a novel intracellular second messenger. J Cell Biol 177: 637-645, 2007.

32. Beyersmann D and Haase H: Functions of zinc in signaling, proliferation and differentiation of mammalian cells. Biometals 14 : 331-341, 2001.

33. Dubben S, Hönscheid A, Winkler K, Rink L and Haase H: Cellular zinc homeostasis is a regulator in monocyte differentiation of HL-60 cells by 1 alpha,25-dihydroxyvitamin D3. J Leukoc Biol 87: 833-844, 2010.

34. Wolford JL, Chishti Y, Jin Q, Ward J, Chen L, Vogt S and Finney L: Loss of pluripotency in human embryonic stem cells directly correlates with an increase in nuclear zinc. PLoS One 5: e12308, 2010.

35. Maret W: Metals on the move: Zinc ions in cellular regulation and in the coordination dynamics of zinc proteins. Biometals 24: 411-418, 2011.

36. Kindermann B, Döring F, Pfaffl M and Daniel H: Identification of genes responsive to intracellular zinc depletion in the human colon adenocarcinoma cell line HT-29. J Nutr 134: 57-62, 2004.

37. Krezel A and Maret W: Zinc-buffering capacity of a eukaryotic cell at physiological pZn. J Biol Inorg Chem 11: 1049-1062, 2006.

38. Schmidt C and Beyersmann D: Transient peaks in zinc and metallothionein levels during differentiation of 3T3L1 cells. Arch Biochem Biophys 364: 91-98, 1999.

39. Apostolova MD, Ivanova IA and Cherian MG: Metallothionein and apoptosis during differentiation of myoblasts to myotubes: Protection against free radical toxicity. Toxicol Appl Pharmacol 159: 175-184, 1999. 